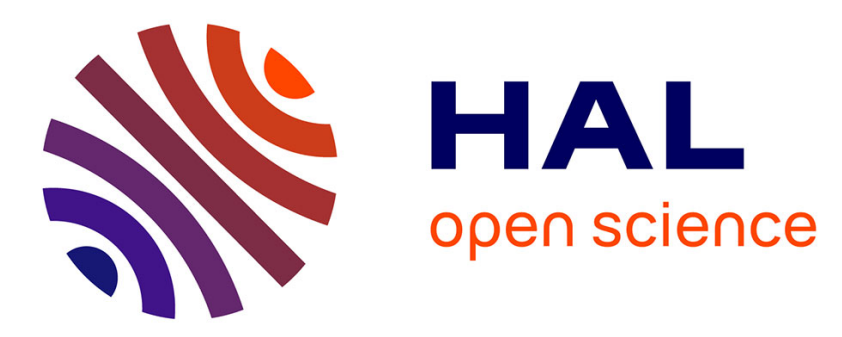

\title{
On the termination of deep-sea fan channels: Examples from the Rhône Fan (Gulf of Lion, Western Mediterranean Sea)
}

L. Droz, I. Jégou, H. Gillet, B. Dennielou, M. Bez, M. Canals, D. Amblas, G. Lastras, Marina Rabineau

\section{To cite this version:}

L. Droz, I. Jégou, H. Gillet, B. Dennielou, M. Bez, et al.. On the termination of deep-sea fan channels: Examples from the Rhône Fan (Gulf of Lion, Western Mediterranean Sea). Geomorphology, 2020, 369, pp.107368. 10.1016/j.geomorph.2020.107368 . hal-03096924

\section{HAL Id: hal-03096924 https://hal.science/hal-03096924}

Submitted on 5 Jan 2021

HAL is a multi-disciplinary open access archive for the deposit and dissemination of scientific research documents, whether they are published or not. The documents may come from teaching and research institutions in France or abroad, or from public or private research centers.
L'archive ouverte pluridisciplinaire HAL, est destinée au dépôt et à la diffusion de documents scientifiques de niveau recherche, publiés ou non, émanant des établissements d'enseignement et de recherche français ou étrangers, des laboratoires publics ou privés. 
On the termination of deep-sea fan channels: examples from the Rhône Fan

\section{(Gulf of Lion, Western Mediterranean Sea)}
L. Droz ${ }^{a}$, I. Jégou ${ }^{a}$, H. Gillet ${ }^{a 1}$, B.
B. Dennielou ${ }^{\mathrm{b}}$, M
M. Bez ${ }^{c}$, M. Canals ${ }^{d}$,
D. Amblas ${ }^{d}, \mathrm{G}$.

Lastras $^{d}$, M. Rabineau ${ }^{a}$

${ }^{a}$ CNRS, UMR 6538 Laboratoire Géosciences Océan, Institut Universitaire Européen de la Mer, Place Nicolas Copernic, 29280 Plouzané, France.

Laurence.Droz@univ-brest.fr, Marina.Rabineau@univ-brest.fr

${ }^{1}$ Present address: Université Bordeaux 1, UMR 5805 EPOC, Avenue des Facultés, 33405

Talence, France. Herve.Gillet@u-bordeaux.fr

${ }^{b}$ IFREMER, Unité de Recherche Géosciences Marines, CS 10070, 29280 Plouzané, France.

\section{Bernard.Dennielou@ifremer.fr}

${ }^{\mathrm{c}}$ Centre Scientifique et Technique Jean Feger, Total, Avenue Larribau, 64018 Pau, France.

\section{Martine.Bez@total.fr}

${ }^{\mathrm{d}}$ CRG Marine Geosciences, Department of Earth and Ocean Dynamics, Faculty of Earth

Sciences, University of Barcelona, 08028 Barcelona, Spain

miquelcanals@ub.edu, damblas@ub.edu,glastras@ub.edu,

\section{Corresponding author:}

L. Droz, CNRS UMR6538, Laurence.Droz@univ-brest.fr

\section{KEYWORDS}

Rhône Fan; turbidite system; terminal lobes; geophysics.

\section{ABSTRACT}

The termination of a deep-sea turbiditic channel represents the ultimate sink of terrigenous sediment in the oceans or lakes. Such environment is characterized by rapid slope decrease and by loss of confinement of turbidity currents. It results in the deposition of Channel-Mouth-Lobes that can be separated from the channel mouth by an erosional (scoured) or by-pass dominated Channel-Lobe Transition Zone. 
Several factors can control the occurrence, extent and morphologic expression of the area such as the slope break angle, the upslope and downslope angle and the $\mathrm{mud} / \mathrm{sand}$ ratio in flows. Disentangling these factors remains challenging due to the scarcity of outcrops and to the usual faint morphologies and low thickness of deposits. With bathymetric and seismic data we calculated the morphometric parameters of 8 channel-levees and their Channel-Mouth Lobes from the deepest area of the Rhone fan, a mud-sand rich system, and among which the youngest one (called neofan) was deposited at the end of the Last Glacial Maximum between 21.5 and $18.3 \mathrm{ka}$ cal. BP. Emplacement and shape (finger-shaped or pear-shaped bulges) of Channel-Mouth Lobes is controlled by the seabed morphology (adjacent channelwhen isolated nascent channels connect to the channel mouth. premature quiescence related to the post sea-level rise sediment starvation. We show that the occurrence and expression of a Channel-Lobe Transition Zone is controlled by the gradient upstream of the channel mouth slope break. The extended Channel-Lobe Transition Zone and detached lobe of the neofan are attributed to the high upslope gradient $\left(0.26^{\circ}\right)$ while the less detached or attached lobes of other channel-levees is attributed to lower upslope gradient $\left(0.13^{\circ}\right)$. We show that scouring and scours concatenation into flutes at the Channel-Lobe Transition Zone is a major driver for the inception of channels and further confinement of turbidity current. For the first time we show that concatenation of scours in shingled disposition developed an incipient channel sinuosity at this very early stage of channel development. The channel-levee can extend downslope nearly instantaneously by tens of kilometers 


\section{INTRODUCTION}

In the long journey of sediment transfer from source to sink, the farthest and deepest sink occurs at the termination of deep-sea turbiditic channels. There, turbidity currents undergo drastic hydrodynamic changes (Komar, 1971), spread out and die out because they lose confinement by levees and lose momentum because of too low gradient. In this context complex sedimentary processes occur. Terminations of turbiditic deep-sea channels are key areas in the partitioning sand in turbidite systems, in sandy systems indeed but also in muddy systems (Piper and Normark, 2001; Pirmez and Imran, 2003; Jégou et al., 2008) and are therefore potential hydrocarbon reservoirs (Piper and Normark, 2001; Zhang et al., 2017).

One striking and ubiquist feature is the occurrence of shifting lobe-shaped bodies referred to as Channel-Mouth Lobe (CML) that show as clusters with a nested compensational stacking pattern reported both in modern and fossil systems regardless of the sediment source type (muddy or sandy) and of the receptacle morphology. Hence, up to five hierarchical units of compensational depositional bodies with increasing thickness and size are commonly described to form clusters named lobe complexes (Deptuck et al., 2008; Prélat et al., 2009; Mulder and Etienne, 2010; Straub and Pyles, 2012). However bodies size and thickness vary and seem controlled by the degree of confinement of the receptacle rather than by the grain size of the sediment (Prélat et al., 2010), though these two characteristics are not independent.

Another striking feature is the frequent occurrence between the channel mouth and the lobes of pervasive erosion in the form of scouring interpreted as a bypass-dominated area and referred to as Channel-Lobe Transition Zone (CLTZ) (Mutti and Normark, 1987). The occurrence of such area controls the connection between the channel-levee and the lobes, which is major concern for the quality of potential hydrocarbon reservoirs (Amy, 2019). When present, a CLTZ is associated to break of slope at the channel mouth and scouring is interpreted as the result of turbidity currents hydraulic jump at the slope break leading to rapid flow expansion and increased turbulence (Wynn et al., 2002a). A CLTZ is however not 
always present and its occurrence maybe related to the slope break angle and to the mudsand amount and turbidity currents efficiency (Wynn et al., 2002a). The question of control by slope and slope breaks remains a matter of debate because recent flume tank experiments have outlined that rather than the angle of the break slope, increased size of a CLTZ is controlled by increased upslope gradient (Pohl et al., 2020), while scouring results from the loss of confinement of turbidity current and resulting flow relaxation (Pohl et al., 2019). CML and CLTZ are evolving dynamic areas as seen by the aggregation of lobes in clusters both in mud rich and sand rich systems (Twichell et al., 1991; Deptuck et al., 2008; Jégou et al., 2008; Migeon et al., 2010; Prélat et al., 2010; Dennielou et al., 2017). They are also areas of fan development and propagation onto the seabed and accompanied by channel inception. Such a geological process is difficult to image in modern systems owing to the partial overlap of lobes and faint morphologic expression on very deep seas hardly resolved by ship hull mounted acoustic tools and whose details are resolved by deep-tow or autonomous vehicles close to the sea bed (Fildani et al., 2013; Carvajal et al., 2017;

Dennielou et al., 2017; Maier et al., 2020). Detailed bathymetric and outcrop based descriptions have outlined the occurrence of erosion and maybe the prerequisite character of erosion and trains of erosional cyclic steps for focusing turbidity currents and initiate accretion of lateral levees (Fildani et al., 2013).

Yet the factors that control the shape, size as well as duration, connection and interaction between channel-levee mouth, CLTZ and CML and their role in fan propagation and channel inception need investigation. In this paper we shed light on the CMLs of the Rhône fan, the second biggest fan in the Mediterranean, categorized as mud-sand rich (Reading, 1991). We investigate the morphometric parameters of 8 recent CMLs, including the youngest one, the neofan, resulting from the channel that developed after the last avulsion near the end of the Last Glacial Maximum (Droz and Bellaiche, 1985; Torres et al., 1997; Bonnel et al., 2005). The opportunity to investigate so many CMLs on the same turbidite system in a geologically short period of time is a great value, as it minimizes the role of external changes and permits 
109 to investigate the role of local factors such as the slope and the maturity of the avulsion on

110 the expression of CMLs.

111 We examine and discuss the origin of the occurrence of a CLTZ and degree of connection

112 between the channel mouth and the lobes. One aim of the study is to quantify the variability

113 of CMLs size and shape within a mud-sand rich turbidite system and to see how it fits in a

114 broad classification scheme (Prélat et al., 2010). We also aim at understanding the role of

115 external factor such as slope, slope breaks and diapirism on the occurrence and

116 morphological characteristics of CLTZs. In this line we also address the question of channel-

117 levee evolution and maturity ensuing an avulsion and possible control on the expression of

$118 \mathrm{CML}$ and CLTZ. Thanks to the exceptional preservation of the CLTZ on the neofan we

119 address the question of channel inception and propagation as well as of sinuosity at a very

120 early stage of inception.

\section{GEOLOGICAL BACKGROUND}

123 Due to the wealth of geophysical and sedimentological data acquired in the Gulf of Lion since

1241965 (Menard et al., 1965), the Plio-Quaternary architecture of the margin and the sediment

125 sources to the basin are well known (Lofi et al., 2003; Leroux et al., 2014; Rabineau et al.,

126 2014; Leroux et al., 2017). Deep-sea sedimentation since the Pliocene was dominated by

127 gravity processes, i.e. turbidity currents and mass-transport processes (Droz and Bellaiche,

128 1985; dos Reis, 2001; dos Reis et al., 2005; Jallet and Giresse, 2005; Droz et al., 2006;

129 Jégou, 2008; Dennielou et al., 2019; Badhani et al., 2020) (Fig. 1a).

130 The outer shelf and slope of the Gulf of Lion are dissected by numerous canyons (Berné et

131 al., 2002a; Berné et al., 2002b; Baztan et al., 2005) that provided pathways to the deep

132 Balearic basin for the Rhodanian and Pyreneo-Languedocian detrital sediments, where they

133 accumulated as turbidite systems since the Plio-Quaternary (dos Reis et al., 2005; Droz et

134 al., 2006). The Rhône Fan, situated in the central part of the Gulf of Lion, is the largest of 
135 these turbidite systems, and comprises a 1500 m-thick accumulation of turbidites and mass-

136 transport deposits (Droz and Bellaiche, 1985; dos Reis et al., 2005).

137 The Quaternary Rhône fan is composed of stacked channel-levee systems grouped into

138 three major complexes (lower, middle and upper complexes from the oldest to the youngest,

139 Fig. 1a) partly overlapping each other and shifted westwards. The channel-levee complexes

140 show a basinward divergent architecture (fan-shaped) from the Petit-Rhône Canyon common

141 point source. The upper channel-levee complex extends from the canyon head to its distal

142 limit along about $350 \mathrm{~km}$ and laterally up to $150-200 \mathrm{~km}$. Time of initiation remains uncertain

143 and was assigned 200-500 ka (Droz et al., 2006) or 900 ka (Leroux, 2012). Recent seismic

144 correlations from shelf reflectors related to lowstands of 100,000 years cycles (Rabineau et

145 al., 2006) and ground-truthed by drill cores (Bassetti et al., 2008) towards the basin allowed

146 refining the basal age of the upper complex to about $450 \mathrm{ka}$ (Leroux, pers. com.). The fan

147 was fed mainly by alpine inputs of the Rhône River (Molliex et al., 2016; Leroux et al., 2017).

148 Fluvial incision of the shelf occurring recurrently during Late Pleistocene sea-level lowstands

149 (during glacial maxima) is known to have connected the Rhône River outlet and the Petit-

150 Rhône Canyon head through a deep incised valley on the shelf (Torres, 1995; Berné et al.,

151 2001; Berné et al., 2002a; Marsset and Bellec, 2002).

152 Several huge mass-transport deposits (MTDs) described on the Gulf of Lion and Catalan

153 margins (Droz and Bellaiche, 1985; Bellaiche et al., 1986; Gaullier et al., 1998; Lastras et al.,

154 2004; Droz et al., 2006; Lastras et al., 2006; Jégou, 2008; Dennielou et al., 2019; Badhani et

155 al., 2020) attest the importance of repeated periods of slope instability during the Quaternary.

156 The youngest of these MTDs (Western and Eastern Upper MTDs) rest unconformably on

157 both sides of the recent channels of the upper complex and were both emplaced during the

158 last lowstand between 22-20 ka BP (Dennielou et al., 2019; Badhani et al., 2020) (Fig. 1a).

159 Following this episode of instability, the Rhône fan underwent a last channel avulsion to the

160 west that led to the abandonment of the southern part of the fan and diverted the deposition

161 in a more proximal part of the fan, to develop the so-called neofan located above the

162 Western MTD. AMS radiocarbon dating indicates that deposits of sediment spillover from the 
163 neofan channel stopped at 18.3 cal. ka BP (age calibrated after Bonnel et al., 2005), i.e.

164 during the onset of the post-glacial sea-level rise (Bonnel et al., 2005; Jégou, 2008).

165 Turbiditic activity persisted upstream of the neofan avulsion until 16.5 cal. ka BP (Lombo-

166 Tombo et al., 2015) and in the western part of the Gulf of Lion during the Holocene (Droz et

167 al., 2001; Bonnel et al., 2005; Dennielou et al., 2009) possibly linked to strong hydro-

168 sedimentary dynamics on the outer shelf (Bassetti et al., 2006) and dense water cascading

169 processes in the canyon heads (e.g. Canals et al., 2006; Gaudin et al., 2006; Palanques et

170 al., 2006).

171 Seafloor mounds related to subsurface salt diapirs influence the topography over a wide area

172 in the distal parts of the fan (Fig. 1b). Diapirs, which result from movement of the Messinian

173 salt during deposition of the Plio-Quaternary sediments, deform the seafloor with mounds up

174 to $250 \mathrm{~m}$ high, and show a great variability in plan-view shapes (either rounded or N-S to

175 NNE-SSW to E-W elongated) and width (from some hundreds of meters to several

176 kilometers).

\section{DATA AND METHODS}

179 In this paper, we document the first complete chronology of the development of the distal

180 Late Quaternary Rhône fan. Based primarily on high- and very high-resolution bathymetric

181 data and sub-bottom profiles (SBP) we show in detail the morphology, seismic facies,

182 architecture and relative chronology of the distal channels and CMLs extending south of

183 latitude $\mathrm{N}^{2} 2^{\circ} 5^{\prime}$. The description of the neofan relies on new data but also takes into account

184 previously published work (O'Connell et al., 1991; Kenyon et al., 1995; O'Connell et al.,

185 1995; Torres et al., 1997; Droz et al., 2001; Wynn et al., 2002a; Droz et al., 2003b; Bonnel et

186 al., 2005; Jégou, 2008). The description of the channels and terminations of channel-levee-

187 lobe systems older than the neofan is entirely based on unpublished data.

188 This study is mainly based on EM300 multibeam bathymetric and backscatter data and sub-

189 bottom profiler (SBP) seismic data acquired during PROGRES 2003 cruise (Droz, 2003; 
Droz et al., 2003b) as part of EUROSTRATAFORM European Program. Additional EM12

191 bathymetric and SBP data acquired during SARDINIA cruise (Aslanian et al., 2006), deep-

192 towed MAK-1M side scan sonar data and $5 \mathrm{kHz}$ sub-bottom profiles acquired during cruise

193 TTR14 (UNESCO Training-Through-Research program) (Kenyon et al., 2006) complement

194 the PROGRES data.

\subsection{Bathymetric data}

196 The EM300 bathymetric data have been combined to produce a $50 \mathrm{~m}$ grid spacing Digital

197 Terrain Model (DTM) in the neofan area at water depths down to $2000 \mathrm{~m}$. For deeper water 198 depths the grid spacing of the DTM is $100 \mathrm{~m}$.

199 In order to enhance the visualization of the low-relief terminal areas of the channels, the

200 PROGRES DTM was processed (Fig. 2) with the SonarScope software developed at Ifremer 201 (https://www.flotteoceanographique.fr/en/Facilities/Shipboard-software/SonarScope). The 202 overall regional slope was subtracted from the DTM (Fig. 2a) by using a polynomial surface 203 (Fig. 2b) corresponding to the mean water depth surface of the southern terminal reaches of 204 the fan. The resulting de-trended DTM (Fig. 2c, d), herein called relief map, delineates zones 205 that are higher and lower than the mean water depth surface (see Picot et al., 2016, for 206 further details on the method).

\subsection{MAK-1M side-scan sonar data}

208 Side-scar sonar data on the neofan were recorded from a deep-towed platform embarking a 209 MAK-1M $30 \mathrm{kHz}$ side-scan sonar. Data were acquired at $2.5 \mathrm{knots}$, about $100 \mathrm{~m}$ above the 210 seafloor, allowing a total swath range of $2 \mathrm{~km}$ with a resolution varying between 7 and $1 \mathrm{~m}$

211 across track and along track respectively. Data consist of $9 \mathrm{~N}-\mathrm{S}$ profiles positioned at the

212 apparent termination of the neochannel, from N42 02 and $\mathrm{N} 41^{\circ} 41$ (Fig. $1 \mathrm{~b}$ ).

\section{3.3. Very high-resolution sub-bottom profiler data}

214 Most of the very high-resolution sub-bottom profiler (SBP) data were acquired from the hullmounted system during the PROGRES cruise (Droz, 2003) at a mean speed of 8 knots in the 
chirp configuration (1.8-5.0 kHz). Data were processed using a simple correlation algorithm

217 (matched filter) followed by an envelope representation (Hilbert transform). SBP data consist 218 mostly in SW-NE strike profiles with 4 to $8 \mathrm{~km}$ of line spacing, crossed by 4 dip lines. SBP 219 profiles allowed the seismic characteristics (facies, overlapping pattern and relative 220 stratigraphy) of depositional bodies to be described. However, in the most distal areas with 221 numerous small depositional bodies intercalated between salt diapirs (Fig. 1), the large 222 spacing of lines $(8 \mathrm{~km})$ did not allow robust stratigraphic correlations.

223 Our study also benefited from hull-mounted chirp data acquired during the SARDINIA cruise 224 (Aslanian et al., 2006) and MD114 cruise (Labeyrie et al., 2003) and from a 5 kHz subbottom profiler installed in the deep-towed MAK-1M platform acquired at 2.5 knots during the 226 TTR14 cruise (Kenyon et al., 2006).

\section{4. RESULTS}

\subsection{Imaging of faint morphologies of CMLs}

The corrected relief map (see Section 3.1, Fig. 2) proved to be a useful tool to enhance subtle topography that characterizes distal parts of fans. This method helped to overcome

231 the difficulties in correlating narrow seismic units across a sometimes widely spaced seismic

232 grid (especially to the southeast) lacking transverse profiles, and allowed the downstream

233 extension of the channels to be defined. It also shows elongated topographic convexities

234 called morphological bulges. From the relief map, we were also able to visualize and characterize small topographic features, such as $10 \mathrm{~m}$ deep scours (in > $2500 \mathrm{~m}$ water

236 depth). However, caution must be taken when interpreting morphological bulges in terms of

237 depositional bodies. The morphological bulges traced from the relief map are positive relief

238 features compared to a regional slope surface. The existence of a bulge is therefore linked to

239 a balance between inherited topography and sediment thickness. Where the thickness is

240 lower than the inherited topographic low between previous units, the deposition is not really 
241 visible as a bulge. Although this is an infrequent situation at the most distal part of the fan,

242 seismic interpretation is necessary to ensure the limit of the depositional units.

\subsection{Channel-levee network}

\subsubsection{Planform morphology and channel chronology numbering}

246 The plan view of the channel network of the Rhône fan shows a basinward diverging, fan 247 shape pattern (Figs. 3, 4a) as for many modern mostly unconfined deep-sea fans on passive 248 margins, such as the Danube Fan (Popescu et al., 2001), the Amazon Fan (Jégou et al., 249 2008) or the Congo Fan (Picot et al., 2016).

250 Based on the plan view morphology and on the geometries observed on SBP, 15 main 251 avulsion nodes with a marked plan view morphological expression and 24 avulsion nodes 252 with a faint morphological expression have been identified. Main avulsion nodes are 253 numbered from 1 to 15 from the oldest to the youngest (Fig. 4). A four-order hierarchical 254 classification of channels developed after avulsion is proposed based on the plan view 255 clustering (Fig. 4 and 5). Thus the Rhône fan channel network is composed of 8 channel256 levees clusters that diverge from the Rhône Valley (Fig. 3). Channel-levees clusters, partially 257 overlapping each other, have developed after 7 main avulsions and have been labelled 7 to 1 258 from old to young with the youngest labelled $\mathrm{N}$ for neochannel (Figs. 3, 4d, 5a). Further 259 downstream, except for channels 5, 1 and $\mathrm{N}$, these channel-levees have undergone second 260 to fourth order avulsions (Fig. 4d), giving rise to a complex network of distributaries.

261 Channels 7 to $\mathrm{N}$ with their distributaries form "groups of channels", so that eight groups of 262 channels characterize the distal fan.

263 It is noteworthy that avulsion nodes of channel groups 7 to 1 (yellow dots in Figs. 4 and 5) 264 continuously stepped basinwards (Fig. 5b), reaching a maximum distance for avulsion node 26514 (from channel 2 to channel 1 ). Consecutively, the neofan shifted abruptly at the most 266 upfan location (avulsion node 15, from channel 1 to N). This continuous basinwards 
migration of main avulsions is balanced by downstream-upstream shifts of second order avulsion nodes (black dots in Figs 4 and 5) defining a higher order of depositional prograding-retrograding trend in an overall prograding pattern.

270 The channels show different morphological characteristics possibly as a function of their age, 271 duration or maturity. To the east, channels 7 to 1 are up to $84 \mathrm{~km}$ long, highly sinuous and 272 have developed between salt diapirs and salt walls (Figs. 1, 4a). Depressions between 273 diapirs are linear normal fault systems reaching the seafloor and related to salt tectonics. The 274 vertical offset of faults reach several tens of meters, up to $50 \mathrm{~m}$. These abrupt topographic 275 variations have affected the evolution of the channels by creating obstacles. Basinward 276 beyond the salt domes, channels diverge and become straighter toward the Balearic Basin, 277 at least until latitude $\mathrm{N} 40^{\circ} 10^{\prime}$ as indicated by still visible portions of channels in this area 278 (black lines in Fig. 4a).

279 In contrast, the neochannel to the west is short, with a length of $20 \mathrm{~km}$ from the avulsion 280 node. It diverges from the abandoned main channel (stacked channels 7 to 1 , Fig. 3c) in a 281 NNE-SSW direction and is rather straight until it bends towards the south, while its imprint on 282 seafloor morphology gradually diminishes, becoming so faint that it is no longer resolved. 283 The morphology of the abandoned main channel (AMC used by channels 7 to 1, Fig. 3c), 284 below the neochannel avulsion node is blurred over about $20 \mathrm{~km}$ because of later sediment 285 infill (Fig. 4b). Droz and Bellaiche (1985) indicate that the infill was due partly to mass286 movement deposition inside the channel that resulted in its obstruction and probably 287 generated the westward neochannel avulsion. Further infill was by fine-grained turbidites 288 from flow stripping and overbanking from the neochannel until 18.3 cal. ka BP. Hemipelagic 289 and/or pelagic deposits probably also contributed to the healing of the relief. Further 290 downstream, the abandoned main channel has developed to the S-SE and maintained a 291 clear topographic expression on the seafloor with a clear sinuous incised channel (Fig. 4b), 292 despite hemipelagic deposition since its abandonment at ca $20 \mathrm{cal}$. ka. The channel floor is 293 perched $200 \mathrm{~m}$ above the surrounding seafloor (Fig. 4c, bathymetric profile A). 
295 The along-channel bathymetric profiles (Fig. 6) show that, prior to abandonment, channels $2962 \mathrm{c} 1,2 \mathrm{bn}, 2 \mathrm{~b} 1,2 \mathrm{a} 1$ and 1 were at equilibrium state (parabolic estimated channel floor profile, 297 black dashed line in Fig. 6a). In contrast, the Rhône Valley and neochannel depth profiles 298 are irregular and comprise a marked knick-point (pink dot in Fig. 6) upstream of the avulsion 299 node (Torres et al., 1997; Bonnel et al., 2005; Jégou, 2008) where channel slope changes 300 from $0.52^{\circ}$ to $1.42^{\circ}$ according to Jégou (2008), indicating that retrogressive erosion inside the 301 Rhône Valley followed the avulsion and was still active until the neofan was abandoned at 30218.3 cal. ka (age calibrated after Bonnel et al., 2005).

303 The retrogressive erosion reached $120 \mathrm{~m}$ of vertical amplitude and propagated $25 \mathrm{~km}$ upstream the avulsion node at an average rate of ca $10 \mathrm{~km} / \mathrm{ka}$ considering the duration of the neofan. This is one to two orders of magnitude slower than knick-points migration velocities measured in presently active channels (Guiastrennec-Faugas et al., 2020; Heijnen et al.,

307 2020) but it is risky to compare changes at annual and millennial time scales. Downstream of

308 the knick-point, the neochannel thalweg slope is rather smooth with a convex-up, near-

309 equilibrium profile and slope gradients decreasing from $0.49^{\circ}$ to $0.26^{\circ}$ until the point where

310 the neochannel is not any more visible.

\section{4.2.3. Seismic facies and architecture}

312 Strike oriented SBP lines across the channel-levees systems reveal typical transparent to

313 stratified wedge-shaped seismic facies in levees and high-amplitude chaotic channel fills that

314 create acoustic masks (Fig. 7). The channel-levee systems rest locally on high-amplitude

315 units. By comparison with high-amplitude reflection packets (HARPs) that characterize

316 avulsion lobes in the Amazon Fan (Pirmez and Flood, 1995; Pirmez et al., 1997; Mansor,

317 2009; Ortiz-Karpf et al., 2015) and in other fans (e.g. Flood et al., 1991; Popescu et al., 2001;

318 Droz et al., 2003a; Schwenk et al., 2005) and considering their locations close to the avulsion

319 nodes, these high-amplitude units are interpreted as avulsion lobes, over which the channel- 
320 levee systems have aggraded and prograded without any evidence of incision into the

321 HARPs

322 The neochannel (Fig. 7a) is bordered by external levees up to $40 \mathrm{~ms}$ twt $(\sim 30 \mathrm{~m})$ thick

323 (Bonnel et al., 2005) and $19 \mathrm{~km}$ wide that rest on a $30 \mathrm{~ms}$ twt ( $20 \mathrm{~m}$ ) thick high-amplitude avulsion lobe. Torres et al. (1997) showed that the southern limit (more precisely the $10 \mathrm{~ms}$ twt seismic thickness, i.e. the resolution of the high-resolution seismic data) of the neofan's HARPs is restricted to Lat. $\mathrm{N} 41^{\circ} 40$. A $2 \mathrm{~m}$ thick hemipelagic drape, indicative of the abandonment of the neofan is observed on seismic profiles (Fig. 7a) and at the top of a core that sampled the external side of the right neofan levee (core MD99-2344 in Bonnel et al., 2005). The channel-levee systems 7 to 1 are 30 to $60 \mathrm{~ms}$ twt thick (20 to $45 \mathrm{~m}$ ), including the basal high-amplitude avulsion lobes, that is $10-15 \mathrm{~ms}$ twt thick $(8-10 \mathrm{~m})$ and can locally contribute to nearly half of the total thickness of the system (Fig. $7 b-c)$. Lateral extensions of these channel-levee systems are not measurable because salt domes interrupt the continuity of the deposits. A lateral extension of about $30 \mathrm{~km}$ has been estimated for system 4b (Fig. 334 7c).

\subsection{Channel mouth areas}

336 The morphology of the channel mouth areas (Figs. 8, 9) is very subtle with relief amplitude

337 generally not in excess of $10 \mathrm{~m}$ and very low average slopes $\left(0.2^{\circ}-0.1^{\circ}\right)$. The bathymetric

338 expression of morphological features is partly a function of the thickness of the post-

339 abandonment sediment cover (i.e. hemipelagic deposition and/or turbiditic overspill deposit

340 from younger channels) and therefore of the age of the depocenters. The resolution of the

341 DTMs (50 $\mathrm{m}$ for the neofan area and $100 \mathrm{~m}$ for older depocenters, see Section 3.1) is

342 another factor hampering a clear assessment of the topographic expression. Therefore, the

343 young neofan shows the morphological features with the highest resolution, and the following

344 description of the morphological features at channel mouths will be based on the

345 observations of the neochannel mouth. 


\subsubsection{General morpho-structural overview of channel mouth areas}

348 The neofan channel-levee system progressively tapers and transitions to a $5 \mathrm{~km}$ long smooth 349 area (Fig. 8a-b) where the seafloor is free of channels. Westward of this smooth area, the seafloor is characterized by numerous, mostly symmetrical depressions ( $<2 \mathrm{~m}$ deep) (giant scours in Fig. 9a) visible on SBP cross lines (Fig. 9a). The seismic facies in this area is

352 transparent, with some discontinuous reflectors at the top, whose exact origin is unknown. A 353 comparison with upstream stratified and laterally continuous overbank deposits (Fig. 7a),

354 suggests that these deposits are different, and related to lobe deposits rather than to levees.

355 The lack of seismic indicators of channel-levee in this area is consistent with the end of 356 channel incision (Fig. 8a-b) and suggests that the sediments exiting the neochannel bypassed (sensu Stevenson et al., 2015) this area to be deposited basinwards. About $4 \mathrm{~km}$ downstream of the sediment bypass dominated area, the seafloor is characterized by pervasive erosional features (Figs. 8, 9b) of two types, i.e. scour marks and elongated channel-like features that are not connected to the neochannel. The channel-like 361 features incise into an almost transparent seismic facies with some discontinuous reflectors forming wedge-shaped seismic bodies (Fig. 9b), less than 20 m thick and apparently thinning outwards from the erosive channel axes. Further south, i.e. $30 \mathrm{~km}$ from the neochannel mouth, erosional features are not observed and the seafloor is smooth and generally free of distributive channel and shows deposits in the form of $10 \mathrm{~m}$ thick wedge-shaped seismic units with highly reflective top surface (Fig. 9c).

The distal portions of channel groups 1 and 2 are characterized on the relief map by positive reliefs (called bulges) surrounding channels and channel mouths, delineating elongated bulges, either narrow (2cn, 2c, 2b1), or pear-shaped (2bn, 2b2, 1) (Fig. 10a). In upstream portions, bulges are 7 to $20 \mathrm{~km}$ wide, and a central sinuous channel is generally identifiable

371 (channels $2 \mathrm{c}$ and 1, Fig. 10b) or inferred (channels $2 \mathrm{~b}$ and 2a, Fig. 10b). The downstream

372 portions of the widest bulges have widths up to $43 \mathrm{~km}$ (bulge $2 \mathrm{~b}_{\mathrm{n}}$, Fig. 10b). The topographic

373 bulges of channel groups 1 and 2 correspond to seismic bodies evolving downstream from

374 channel-levee systems up to $25 \mathrm{~ms}$ twt $(\sim 19 \mathrm{~m})$ thick, with well-identified stratified to 
transparent external levees (Fig. 11a), to wedge-shaped seismic sub-units made of a combination of chaotic facies with very high-amplitude reflectors, and transparent facies

377 (Fig.11b-d).

378 The seismic analysis provided some clues to establish a relative chronostratigraphy for the identified seismic sub-units (Fig. 4d). However, wedge-shaped sub-units are numerous and, except for bulges $2 b$ and $2 a$, due to the low penetration of SBP data and the scarcity of transverse profiles to correlate these small sub-units, the chronostratigraphic relationships between the seismic sub-units remain incomplete and/or uncertain. The bathymetric bulges $2 \mathrm{~b}$ and $2 \mathrm{a}$ are sub-divided into at least 2 to 4 successive seismic sub-units, 8 to $20 \mathrm{~ms}$ twt ( 6 to $15 \mathrm{~m}$ ) thick and generally thinning downfan (Figs. 10,11). Some evidences of backstepping geometries are observable at the distal part of this system (Fig. 12, north-western part of the profile).

\subsubsection{Detailed seafloor morphology}

The Rhône fan terminal areas are characterized by erosional features (scours) and depositional elements (wedge-like features) that can be spatially separated or coeval. In the neofan, they are clearly linked to changes in slope (Fig. 6). Such erosional and depositional bedforms are also observed in the terminal parts of channel groups $2 b$ to 1 (Fig. 10).

393 Longitudinal slope analysis for bulges $2 \mathrm{c} 1$ to 1 (Fig. 13) shows small gradients (average

$3940.12^{\circ}$, Fig. $6 a$ ), decreasing from $0.18^{\circ}$ upstream to $0.09^{\circ}$ downstream where the fan merges 395 with the flat Balearic abyssal plain. Scours and unconnected channels are identified on 396 slopes $\left(0.13^{\circ}\right.$ to $0.10^{\circ}$, Fig. 13$)$ lower than those of the neofan $\left(0.21^{\circ}\right.$, Fig. 6$)$. The 397 bathymetric profiles of channels $2 \mathrm{~b}$ to 1 and their lobate extension show more regular 398 decrease of slopes than the neochannel, with no major slope break, even at the avulsion 399 nodes. Note that slope of these fossil channel-lobes is measured from straight lines at the 400 channel axes and do not account for the sinuosity of the channels. Consequently, calculated 401 slope of the old channel-lobes tends to be overestimated except in the terminal parts where 402 channels are mostly straight. 
405 Downstream the neofan and neochannel numerous scour marks are observable on bathymetric data (Fig. 6). The scours are characterized by asymmetrical dip profiles, with steeper updip flanks. On strike profiles they are either symmetrical or asymmetrical (S or A, respectively, on Fig. 14). The scours on the neofan occur on a mean slope of $0.21^{\circ}$ (Fig. 6) and show various dimensions. On the right outer levee of the neochannel coalesced giant scours, 10-30 m deep, 1-2 km wide and 1-5 km long scours (Figs. 8b, 14a) previously described by Kenyon et al. (1995), Bonnel et al. (2005), Jégou (2008) and Dennielou et al.

412 (2009) have an updip flank mainly oriented NW-SE. Smaller scours, 5-10 m deep, less than $413500 \mathrm{~m}$ wide characterize the area of the neofan located off the termination of the neochannel 414 (Figs. 8b, 14a). The updip flanks of small scours are mainly oriented E-W, i.e. more or less transverse to the neochannel termination. They evolve downstream to smaller triangular chevron-like scours that progressively disappear southwards (Fig. 14a).

Scour marks are also observed at the top of bulges 1 and 2 (Fig. 14d) in the form of several meters deep depressions that are generally symmetrical but can also be asymmetrical in some cases with flanks sloping at different angles (strike lines in Fig. 14d). The deepest depressions are $5 \mathrm{~m}$ deep and $300 \mathrm{~m}$ wide, but most often the width of these features is 100 $200 \mathrm{~m}$, regardless of the symmetry. Scours on bulges are hardly resolvable on SBP sections where they are mainly expressed as hummocky areas (Figs. 10b, 11b). At the distal part of the by-pass area, at the termination of the neochannel, in an area of low slope gradient $\left(\sim 0.2^{\circ}\right)$, SBP strike lines show $10 \mathrm{~m}$ deep erosive features (Figs. 14a, 15) incising an almost transparent substrate, with few discontinuous reflectors. In plan-view, 428 these erosional features are elongated (up to $15 \mathrm{~km}$ long) and narrow (generally less than $429500 \mathrm{~m}$ wide) channel-like features (called Ch1 to Ch3, without any chronological order 
430 inferred). A fourth channel-like feature (Ch4, Fig. 15a) is located upslope at the outer bend of

431 the first bend of the neochannel.

432 High-resolution $5 \mathrm{kHz}$ SBP profiles fail to reveal the relative age of these channel-like

433 features with regard to the neochannel, but show that these conduits do not develop external

434 levees and appear as purely erosional features. Detailed topographic analysis of the

435 channel-like features (Fig. 15b) allows numerous E-W oriented $<500$ m wide, semi-circular

436 scours to be identified along their length, similar to those of the small scours field. On very

437 high-resolution MAK-1M side-scan sonar, these scours show downchannel facing headwall

438 scarps prolonged by elongated erosional lows. On MAK-1M $5 \mathrm{kHz}$ SBP, the scours are

439 symmetrical on transverse cross sections ( $\mathrm{s} 1$ and $\mathrm{s} 2$ in Fig. 16b, c) and asymmetrical with a

440 steeper headwall when longitudinally crossed (s3 and s4 in Fig. 16b, c). The maximum depth

441 of the scours is $14 \mathrm{~m}$ at the Ch2 channel head (Fig. 16b), decreasing to $11 \mathrm{~m}$ at the southern

442 part of Ch2 (Fig. 16c). Because of their shape and size, these erosion features can be

443 named megaflutes (Lonsdale and Hollister, 1979; Elliott, 2000; Kane et al., 2009). Changes

444 in the channel Ch2 direction are controlled by offsets of the megaflute clusters (about $200 \mathrm{~m}$

445 wide).

446 In addition, MAK-1M mosaic reveals NE-SW to NNW-SSE lineations (Fig. 16a) inside the

447 head of Ch2 and outside this channel, especially on its right hand side. These lineations

448 slightly diverge downslope from an area that could be the outer part of the first bend of Ch1,

449 while Ch2 appears to be superimposed to them.

450 On the morphological bulges and wedge-shaped seismic units related to channels 1 and 2

451 (Figs. 11b, 12), small channels, $7 \mathrm{~m}$ deep at maximum, also appear to be unconnected to the

452 main feeder channel of the bulge (Fig. 10). Most of these small, unconnected distributaries

453 appear on seismic lines as erosional features at the top of the units and could correspond to

454 channel-like features similar to those identified on the neofan. However, in contrast to the

455 neofan, the unconnected channels show frequent evidences of associated small external

456 levees, possibly made of coarse-grained deposits owing to their high amplitude seismic

457 facies (channel 2a1 in Fig. 12). 


\subsubsection{Depositional features}

460 The distal part of the neofan, downsteam of the chevron-like scours, is characterized by a 461 very smooth topography on a mean slope of $0.13^{\circ}$ (Fig. 6). The seismic profile provided in 462 figure 9c shows wedge-shaped transparent seismic bodies with highly reflective top surface, 463 less than $7 \mathrm{~m}$ thick and $5 \mathrm{~km}$ wide, and irregular rounded top morphologies and flat bases. 464 Jégou (2008) identified a total of 11 of such seismic bodies with mean thicknesses of 10-15 $465 \mathrm{~m}$ (minimum few meters and maximum $45 \mathrm{~m}$ ) in the neofan and extended the distal limit of 466 the neofan near $\mathrm{N} 40^{\circ} 45$, i.e. about $160 \mathrm{~km}$ from the neochannel bifurcation point. Terminal 467 areas of morphological bulges 1 and 2 are characterized by similar wedged-shape seismic 468 units (Figs. 11b-d, 12), with comparable seismic facies (combination of high amplitude 469 chaotic facies and transparent facies) and sizes (see Table 2). The most superficial wedge470 shaped units are $15 \mathrm{~ms}$ twt $(\sim 10 \mathrm{~m})$ thick upfan (bulge $2 \mathrm{~b}$, Fig. 11b) with a clear tendency to 471 thin downfan (7 ms twt, i.e. $5 \mathrm{~m}$ for bulge $2 \mathrm{~b} 1 \mathrm{in}$ Fig. 11c). Several older and buried wedge472 shaped units can be identified on SBP data, but due to loss of penetration in these probably 473 coarse-grained environments an accurate thickness cannot be constrained.

\section{DISCUSSION}

\subsection{Significance of morpho-sedimentary domains}

477 The main geometrical characteristics of morpho-sedimentary domains are summarized in 478 figure 17 and Table 1. The Rhône fan morphological bulges extend for significant distances, 479 i.e. $92 \mathrm{~km}$ to $158 \mathrm{~km}$, and contribute from $25 \%$ to $43 \%$ of the $370 \mathrm{~km}$ total length of the fan 480 (Fig. 17, Table 1). Three morpho-structural domains can be identified from upstream to 481 downstream, which are well expressed in the western young neofan, and tentatively 482 recognized in the eastern older and more distal bulges. 
483 In domain 1, depositional processes are dominant in the form of aggradational, up to $30 \mathrm{~m}$

484 thick channel-levee systems that have developed upstream on top of avulsion lobes

485 (HARPs) (Flood et al., 1991; Lopez, 2001; Bonnel et al., 2005) close to the avulsion nodes.

486 Erosional processes are dominant in domain 2, in the form of 10 to $30 \mathrm{~m}$ deep erosional

487 features at different degrees of evolution (scours and slightly sinuous channel-like features).

488 These erosional features are interpreted as the result of flow transformation associated with

489 a break of slope and are commonly described in transition areas between well-defined

490 channel-levees and well-defined lobes (CLTZ) (Mutti and Normark, 1987; Wynn et al., 2002a;

491 Brooks et al., 2018). In domain 3, depositional processes dominate on a nearly flat seafloor

492 in the form of stacked $10 \mathrm{~m}$ thick (exceptionally $45 \mathrm{~m}$ thick) wedge-shaped, possibly

493 channelized seismic units, interpreted as Channel-Mouth Lobes.

494 The bypass and erosion dominated domain 2 is well-constrained and well developed in the

495 neofan at the end of the neochannel. The exceptional preservation of the erosion marks on

496 the seafloor points to a very abrupt sediment starvation related to the last sea level rise and

497 disconnection of the Rhône River and the Petit-Rhône Canyon (see Section 5.2).

498 Conversely, domain 2 seems poorly developed or absent at the eastern channel

499 terminations. However, the bathymetric expression of the CLTZ was possibly altered by

500 subsequent burial.

501 Plotting the maximum width versus maximum thickness of domain 3 for channels $N, 1,2 a 1$,

$5022 \mathrm{~b} 1$ and 2bn (measurements provided in Supplementary Material) allows referring to domain

5033 as unconfined lobes of Prélat et al. (2010) classification (Fig. 18a). This is confirmed by

504 plotting the aspect ratio (length/width) to the maximum thickness/area of these domains (see

505 Supplementary Material for surface calculation). Maximum thickness/area ratio is $\sim 10^{-5}$ (Fig.

506 18b) similar to that of unconfined lobes of Tanqua Karoo, Amazon and Congo fans with an

507 average aspect ratio of 2.8 (1.9 to 5.8) (Prélat et al., 2010). These results confirm our

508 hypothesis that the morphological bulges of domain 3 can be interpreted as lobes. 


\subsection{Controls on avulsions}

511 Channel avulsion is a major process in the development of deep-sea fans. It is admitted that

512 the occurrence and location of avulsions is a natural consequence of the development and

513 growth of a channel-levee that cannot indefinitely increase. Therefore avulsion can be

514 controlled by external (sea level and climate changes and consequences on type and

515 quantity of sediment input to the fan) and internal (slides, breaching, spillover processes,

516 thalweg aggradation) forcings that are most of the time entangled and is, like for slope

517 stability processes, a combination of preconditioning factors and trigger mechanisms (see

518 review in Kolla, 2007). On the Rhône fan distal reaches the lack of chronological constrain

519 for channel-levees 7 to 1 prevent to conclude on the external factors that controlled avulsions

520 and their continuous basinward migration (Fig. 5b). One can argue that their emplacement

521 and development were most probably autogenic though slightly controlled by diapirs growth.

522 On the other hand, it is noteworthy that avulsion of the neochannel is remarkably different as

523 it occurred in a very up-dip position on the flank of the Rhône Valley and that the neofan

524 have developed on a higher slope gradient (Fig. 6). The emplacement of the neofan is

525 concomitant with two major external events that could explain the trigger of the avulsion.

526 The neofan has developed on top of a voluminous mass-transport deposit, the Western

527 Mass Transport Deposit (WMTD), that emplaced between 21.5 and 19.9 ka cal BP

528 (Dennielou et al., 2019) and that is deeply incised by the neochannel. Interestingly, the

529 avulsion node lies right above one of the headscars related to the slide, suggesting a causal

530 relationship between the slide and the avulsion. This hypothesis is supported by the fact that

531 external flanks of the Rhône valley, both to the west and to the east, show several massive

532 headscars related to these Last Glacial Maximum (LGM) slidings (Dennielou et al., 2019;

533 Badhani et al., 2020), that nearly reached the inside of the valley and the thalweg, creating

534 favorable conditions for breaching, crevasse splay and eventually channel avulsion (Torres

535 et al., 1997). A similar process was suggested for triggering an avulsion on the Magdalena

536 Fan (Ortiz-Karpf et al., 2015). 
537 The neofan was emplaced during the LGM, a period of maximum sediment accumulation on

538 the Rhône fan (Lombo-Tombo et al., 2015), before the last sea level rise and a sediment

539 starvation. High sedimentation rates in the valley were also characterized by coarser

540 deposits (Lombo-Tombo et al., 2015) that could have increased the thalweg aggradation and

541 lead to increased turbiditic overflow and diversion of turbidity currents. Several evidences of

542 levee erosion related to flow spillover are found upstream the neofan (Droz et al., 2001;

543 Bonnel et al., 2005), supporting the hypothesis that several areas of enhanced lateral

544 spillover were potential candidates for channel avulsion. In the same line, thalweg blocking

545 by sliding of channel inner flank and also possibly related to enhanced accumulation has

546 been also invoked for the neochannel avulsion trigger mechanism (Droz and Bellaiche, 547 1985).

\subsection{Mature versus immature channel avulsions}

550 The successive changes of architecture, size and topography of domains 2 and 3 of bulges 1

551 and 2 are similar to those observed on the neofan (Table 2).

552 The channel avulsion that formed the neofan occurred in a more proximal position than those

553 of eastern channels 2 to 1 (Fig. $5 b$ ), and consequently the neochannel is characterized by

554 much higher along-channel gradients $\left(0.26^{\circ}\right.$ to 0.13 , Fig. 6$)$. It is also characterized by a

555 major knick-point upstream of the avulsion node indicating that retrogressive erosion did not

556 result in the establishment of a new equilibrium profile, and that the neochannel was at an

557 immature stage when it was abandoned. This suggests that the ca. 2-3 kyr duration of the

558 neofan was insufficient to establish the equilibrium profile in the neochannel after the

559 avulsion. In contrast, avulsion of channels 7 to 1 occurred in more distal positions and

560 channels developed on smaller along-slope gradients $\left(0.15^{\circ}\right.$ to $0.09^{\circ}$, Fig. 13). No along-

561 channel knick-point or significant breaks in slope are observed in channels $2 \mathrm{c}$ to 1 , even

562 close to avulsion nodes, indicating that these channels had probably reached an equilibrium

563 profile when they were abandoned. The distal occurrence of these avulsions, i.e. on smaller 
564 slopes, probably favored a rapid establishment of the equilibrium profile and therefore

565 durations longer than the neofan duration are not necessarily needed. However, the

566 existence of small external levees associated with unconnected channels of lobes 2 (Fig.

567 12), which do not exist in the neofan, suggests that these unconnected channels had

568 sufficient time to become permanent pathways for turbidity currents and to build external

569 levees. This leads us to envisage that the eastern channels-lobes 7 to 1 were more mature

570 than the neofan when they were abandoned. This is also suggested by the sinuosity of the

571 channels that supports their maturity as seen in other turbidite systems (e.g., Peakall et al.,

572 2000; Babonneau et al., 2002; Deptuck et al., 2003). Durations of turbiditic lobe activity are

573 rarely reported in literature. The duration of the neofan, between 1.2 and $3.2 \mathrm{kyr}$ is inferred

574 from the age of its onset on top of the WMTD, between 19.9-21.5 ka cal. BP (Dennielou et

575 al., 2019), and the post-seal level rise sediment starvation at $18.3 \mathrm{ka}$ cal. BP (age calibrated

576 after Bonnel et al., 2005). Migeon et al. (2010), indicate duration longer than $2.5 \mathrm{kyr}$ for the

577 Nile Fan terminal lobes. In contrast, in the Amazon Fan, Jégou et al. (2008) estimated to 0.6

578 kyr the duration of individual lobes constituting the youngest lobe complex, whereas Picot

579 (2015) inferred highly variable durations of channel-lobes systems in the Congo Fan, with the

580 youngest lobe of the last lobe complex being deposited during $0.46 \mathrm{kyr}$. These disparities

581 suggest that channel and lobe durations are highly variable and probably relate to numerous

582 controlling factors, e.g. sea-level and climate controlled sediment input, frequency and

583 magnitude of flow, loci of avulsions, accommodation conditions related to previous

584 depositional and mass-transport episodes and transport capacity of turbidity currents.

585 However this comparison with duration of other channel-levee-lobe systems is challenging

586 considering that a common definition of lobes is not provided in these papers.

588 5.4. Controls on bulges emplacement and sedimentation

589 The elongated and narrow or pear-shaped (Fig. 17) planforms of the Rhône fan bulges

590 (domains 2 and 3), and the compensational stacking pattern of seismic units (Figs. 11, 12) 
591 support an interpretation that their emplacement was controlled by topographic

592 compensation through the restricted available space. This is obvious for seismic unit $2 \mathrm{~b} 1$ and

593 2bn (Fig. 11) where sub-units have a clear compensational architecture. The neofan also

594 clearly shows a topographic confinement by the older Rhône fan to the east and the WMTD

595 and deposits from the Catalan channels to the west (Fig. 17). A compensational stacking

596 pattern is also shown by the alternative eastward and westward migrations of the sub-units

597 (violet dashed arrows in figure 17). However, besides this compensational growth pattern,

598 CMLs $2 b$ to 1 and $\mathrm{N}$ have morphometric parameters compatible with the unconfined lobes of

599 (Prélat et al., 2010) (Fig. 18), suggesting that topographic confinement is not the principal

600 controlling factor of the growth pattern.

601

\subsection{Channel-Lobe Transition Zone: characteristics and occurrence}

603 In turbidite systems, channel-lobe transition zones (CLTZ) are critical areas where turbidity 604 currents undergo hydro-sedimentary changes associated with breaks of slope and loss of 605 confinement (Wynn et al., 2002a; Dorrell et al., 2016; Pohl et al., 2019). CLTZ are dynamic 606 areas evolving through time (Brooks et al., 2018) and are commonly bypassed by sediments 607 and characterized by patchy coarse deposits, abundant erosional features such as scours 608 and (coarse-grained) sediment waves (Wynn et al., 2002b; Macdonald et al., 2011; Shaw et 609 al., 2013; Hofstra et al., 2015).

610 Domain 2 of the recent Rhône neofan is interpreted as a CLTZ because of the presence of 611 multiple erosional features which coincides with an abrupt slope break in the prolongation of 612 the neochannel (Wynn et al., 2002a). The more distal domain 3, free of erosional features, 613 could therefore be interpreted as a detached lobe(sensu Mutti and Normark, 1987; Van der 614 Merwe et al., 2014).

615 In channel-lobes 7 to 1, domain 2 (hummocky scoured seafloor, Fig. 17a) are observed only 616 at the mouth of channels 1, 2a1, 2b1, 2cn (Supplementary Material and Fig. 17a), and are 617 generally less extended longitudinally (17-26 km, exceptionally $39 \mathrm{~km}$ for bulge 2a1, 
618 Supplementary Material) than on the neofan $(40 \mathrm{~km})$. This striking difference may come from

619 lower resolution of the DTM in this area but may also be related to real morphological

620 differences between these sites. Hummocky morphologies (Figs. 11b, 12b), interpreted as

621 scour fields, do not appear to be linked to significant slope breaks (slope decreases

622 progressively from $0.15^{\circ}$ to $0.09^{\circ}$ ) and the average slope of $0.12^{\circ}$ is similar to that of the

623 neofan $\mathrm{CML}\left(0.13^{\circ}\right)$. Moreover, we do not identify a sediment bypass-dominated zone at the

624 end of channels 2 and 1 . Unless this absence is related to post-avulsion modifications, this

625 could indicate that the domains 2 and 3 of eastern lobes formed attached lobes (Wynn et al.,

626 2002a) where scouring may also occur.

627 Our results show that drawing a universal model for the occurrence and expression of a

628 CLTZ is challenging because these can even change in space and time in a given fan. Two

629 key parameters, generally considered as control factors, are the composition of flow (muddy

630 versus sand rich) and channel mouth slope break (Wynn et al., 2002a). Slope evolution

631 along the terminal parts of channels appears indeed as a strong topographic control.

632 Domains 1 (channel-levee) to $3(\mathrm{CML})$ of the neofan show a clear link with slope breaks.

633 Although slope is very low $\left(0.26^{\circ}\right.$ to $\left.0.13^{\circ}\right)$, the rate of change (decrease) is high, i.e. $19 \%$

634 from aggradational channel-levee $\left(0.26^{\circ}\right)$ to erosional $\operatorname{CLTZ}\left(0.21^{\circ}\right)$ and then up to $38 \%$ to

635 depositional $\mathrm{CML}\left(0.13^{\circ}\right)$. Such low slopes but high rates of change have been demonstrated

636 to be a major control on thickness variations of turbiditic beds, and behavior of turbidity

637 currents in the Moroccan turbidite system (Sumner et al., 2012) and Ogooue Fan (Mignard et

638 al., 2019). The correlation between changes in slope and erosion or deposition of eastern

639 older lobes is less obvious since longitudinal slopes evolve more gradually without major

640 slope breaks (Figs. 6a, 13).

641 Along the neochannel, the backstepping knick-point and retrogressive erosion suggest that

642 turbidity currents were much sandier than along the eastern channels. According to the

643 conceptual model in Wynn et al. (2002a), this should have promoted low efficiency flows and

644 a CLTZ smaller than to the east but this not the case. Therefore, the extra sand eroded from

645 the neochannel did not significantly modified flow efficiency or change in efficiency was 
646 largely outpaced by another parameter such as the upper slope and slope break that are 647 much higher than to the east.

648 Recent shield scaled flume tank experiments made a breakthrough in the comprehension of 649 channel-mouth turbiditic processes, showing that lobe detachment and scouring are related 650 to separate processes (Pohl et al., 2019; Pohl et al., 2020). The occurrence of scours is not 651 necessary only related to slope break and hydraulic jump but more to the loss of confinement 652 and subsequent flow relaxation (Pohl et al., 2019). On the other hand, the occurrence and 653 size of the bypass-dominated area and the thickness of detached depositional area are 654 controlled by the steepness of upper and lower slopes of the slope break rather than by the 655 angle of the slope break (Pohl et al., 2020).The morphological expression of CLTZs is 656 therefore a subtle combination of these controls, keeping in mind that a hydraulic jump will 657 still promote erosion at a slope break. On the neofan, the large scoured area, possibly 658 bypass-dominated, is consistent with the steep upper slope $\left(0.26^{\circ}\right)$ as shown by flume 659 experiment (Pohl et al., 2019) while on eastern channels, smaller of absent scoured-bypass 660 areas are consistent with the gentle upper slope $\left(0.11-0.15^{\circ}\right)$ (Figs. 6a, 13). As the 661 expression and extension of scouring may be controlled by degree of detachment of lobes, it 662 is therefore also indirectly controlled by the steepness of the upper slope. The degree of 663 scouring may be related to the abruptness of the loss of confinement and flow relaxation 664 (Pohl et al., 2020) but this is a parameter that we cannot measure. However the much bigger 665 scours found on the neofan may be a direct consequence of bigger hydraulic jump related to 666 the channel mouth bigger slope break.

\subsection{Erosion in CLTZ: a key parameter for channels and meanders inception}

669 Channels disconnected from the main channel, also called "headless" are common features

670 and occur at shallow and deep-water, in small and big sedimentary systems like on pro-

671 deltas (Gales et al., 2019), in fjords (Heijnen et al., 2020), in lakes (Girardclos et al., 2012)

672 and on deep, basin wide, turbidite systems (Fierens et al., 2019). Here we discuss their 
673 inception together with the related topic of channel sinuosity that are thoroughly addressed in

674 scientific publications (Peakall et al., 2000). Channel development is commonly described as

675 a gradual process dominantly driven by levee development and subsequent erosion

676 (Sylvester et al., 2011) but also to some extent by erosion in the channel (Babonneau et al.,

677 2002). Yet, their inception from a flat seafloor is poorly known and rarely addressed. If

678 gradual confinement of turbidity current by levee aggradation is commonly admitted, it has

679 also been outlined that seafloor erosion may play a crucial role in initial flow confinement,

680 subsequent spillover processes and eventually channel inceptions (Normark et al., 2005;

681 Fildani et al., 2006; Lastras et al., 2011; Fildani et al., 2013; Covault et al., 2014; de Leeuw et 682 al., 2016; Hodgson et al., 2016; Gales et al., 2019). Scours of various sizes and shapes are 683 well known on channel floors, overbank areas and CLTZs of many turbidite systems (e.g.

684 Palanques et al., 1995; Elliott, 2000; Kenyon et al., 2002; Wynn and Stow, 2002; Fildani and 685 Normark, 2004; Klaucke et al., 2004; Masson et al., 2004; Fildani et al., 2006; Macdonald et 686 al., 2011; Maier et al., 2011; Fildani et al., 2013; Shaw et al., 2013). In the neofan CLTZ, 15 $687 \mathrm{~km}$ long and $10 \mathrm{~m}$ deep channel-like features detached from the outlet of the feeding channel 688 (Figs. 15, 16) are built by longitudinally concatenated megaflute scours (Fig. 16) indicative of 689 turbulent erosive flows (Kenyon et al., 1995; Wynn et al., 2002a; Peakall et al., 2020) on this 690 very low gradient seafloor $\left(0.21^{\circ}\right)$ at the termination of the neochannel. In addition to a 691 longitudinal concatenation, the lateral offset and shingled disposition of megaflutes mimics 692 an incipient sinuosity (Fig. 19A, B). This leads us to envisage that these megaflutes may not 693 only play a major role in channels inception but may also control, at a very early stage, a 694 sinuous pattern that is commonly interpreted as a mature stage channel-levee pattern 695 (Babonneau et al., 2002). We therefore propose that the megaflutes represent the 696 elementary structures that serve as guides to develop preferential pathways for repeated 697 erosive flows. By their constricting effects on unchannelized flows, they will eventually 698 progressively connect and evolve into immature sinuous channel-like features. The 699 confinement of turbidity current in such sinuous erosional channels (Fig. 19 B4-5) may 700 eventually develop external levees through flow striping and overspill processes and evolve 
701 into channel-levee systems, (as observed for channel 2a1 for example, Fig. 12). This gradual

702 development of channel will result in the gradual confinement of turbidity currents, decrease

703 of flow relaxation and hydraulic jump and, eventually, forestepping of the CLTZ and burying

704 of the abandoned scour marks and channel-like features under the newly developed levees,

705 as proposed in the conceptual model of Hofstra et al. (2015).

706 We also assume that this process may eventually lead to the connection of the channel

707 mouth with one of the scour-controlled channel which will virtually achieve an instantaneous

708 progradation of the channel and channel mouth over several kilometers (Fig. 19B4-5). This

709 hypothesis explains that the two observed scour-fields with scours of different orientations

710 can be related to instantaneous channel mouths downslope migration (Fig. 19 C), illustrating

711 that the channel mouths and CLTZ are dynamic area as shown in Brooks et al. (2018). This

712 prograding process could also explain why CLTZ is not clearly observed at the outlet of

713 channels 2 to 1.

714 It is noteworthy that scouring by currents of several kinds (contour currents, turbidity

715 currents) and concatenation of scours into scour fields seem to be a major driver of channel

716 and canyon inception in several environments. It is for instance invoked for the inception and

717 bottom-up development of canyons on the Argentine Continental Margin under the cross

718 processes of scouring and scours amalgamation by along-slope bottom currents and further

719 containment and draining of across-slope turbidity currents (Lastras et al., 2011). It is also

720 invoked for the inception of a channel avulsion on the Monterey Fan (Shepard Meander in

721 Fildani et al., 2006; Fildani et al., 2013). Our case study has similarities with the channel

722 inception on the Shepard Meander because it involves scouring by turbidity currents

723 undergoing a hydraulic jump. It is however different because on the neofan, concatenation of

724 scours occurs in the CLTZ, on a much flatter seafloor, and is, in addition, a driver for the

725 development of channel sinuosity and for instantaneous channel progradation. 


\section{CONCLUSIONS}

729 The morphology and the depositional architecture of channel mouth lobes of the Rhône fan,

730 key architectural elements of turbitite systems, have been documented at high resolution for

731 the first time via fine processing of DTMs, which appears as a helpful technique to highlight

732 small topographic variations that are highly relevant to the identification and interpretation of

733 depositional units in those environments. The opportunity to examine 8 channel avulsions

734 and ensuing development of channel-levee, CLTZ and CML on a given mud-sand rich fan,

735 the Rhône fan, have allowed to assume potential minimum external forcing from sea level

736 and sediment flux changes and discuss the role of internal factors on the expression and

737 development of channel avulsions, channel-levees systems, CLTZs and CMLs and to draw

738 the following conclusions:

739 - Channel mouth lobes of the distal Late Quaternary Petit-Rhône deep-sea fan appear as elongated finger-like or pear-shaped bulges at the terminal part of a tree-like network of channel-levee systems. Their shapes and internal structure show that their emplacement is controlled by the topography and by compensational processes.

- Two main sets of channel-levee systems constitute the Late Quaternary turbidite system. The youngest, the neofan (21.5 to 18.3 cal. ka B.P.), was deposited upfan, at lower depths $(2000-2500 \mathrm{~m})$ with higher slope gradients $\left(0.26^{\circ}\right)$ and the neochannel was not at an equilibrium state when it was abandoned. The older channels to the east, running on the most distal parts of the fan (2500 to $2800 \mathrm{~m}$ water depth) on lower gradient $\left(0.13^{\circ}\right)$ appear to be at equilibrium.

- Straighter channel-levee and bad development of external levees along channels of the CML on the neofan are indicative of a lower maturity than eastern channel-levees and CMLs

- Channel-mouth lobes display noticeable morphosedimentary similarities independently of their age. The neofan shows three main domains succeeding from upstream to downstream: (1) the channel-levee system domain dominated by aggradation and channelization; (2) the Channel-Lobe Transition Zone (CLTZ) 
domain sensu stricto with scours and channel-like features indicative of the prevalence of erosional or bypass-dominating processes; and (3) a transparent lobes domain with deposition and possibly channelization.

- On the neofan an important extension of the scoured CLTZ and detachment of the CML to the channel-levee is promoted by a high upslope before the slope break

\section{AKNOWLEDGEMENTS}

PROGRES cruise was a contribution to the EUROSTRATAFORM European Program, (contract $n^{\circ}$ EVK3-2001-00200) and to the French Program Action Marges. This work was later realized in the framework of the Labex Mer (axis 4: Sediment transfer from coast to abyss). GRC Geociències Marines was funded by the Catalan Government (grant 2017 SGR 315) within its program for excellence research groups. Intergovernmental Oceanographic Commission (IOC) of UNESCO funded the TTR14 cruise. I. Jégou was financed by Shell during her $\mathrm{PhD}$ and $\mathrm{H}$. Gillet benefited from a post-doctoral fellowship funded by Total. We thank the Captain, crews and onboard scientists of the R/Vs Le Suroit of Ifremer and Professor Logachef operated by the Polar Marine Geosurvey Expedition (PMGE, St. Petersburg, Russia) onboard which PROGRES (2003) and TTR14 (2004) cruises were conducted, respectively. We acknowledge the technical team from Genavir for data acquisitions during PROGRES cruise. Onboard data processing was performed by E. Le 
783 Drezen and A. Normand from Ifremer and M. Rabineau, J. Baztan, G. Jouet and E. Leroux

784 from UMR6538. P. Ferrer performed part of the shore-based processing of SBP data during

785 his Master 2 research work. We acknowledge D. Aslanian (Ifremer) for permission to use and

786 publish some data acquired during the SARDINIA cruise and J.-M. Augustin (Ifremer) who

787 provided training and help for the processing of the PROGRES DTM under the SonarScope

788 software. We are grateful to Pr. D. M. Hodgson and Pr. P. J. Talling for their constructive

789 reviews, which significantly contributed to improve the manuscript. 
791 Figure 1: Location of the studied area in the framework of the Gulf of Lion, Catalan Margin 792 and Balearic Basin, modified from Droz et al. (2006). (a): Physiographic map showing the turbidite systems (light grey) originating from the northern margin of the Western Mediterranean and mass-transport deposits (dark grey) on the Petit-Rhône fan. (b): Shaded bathymetric map of the Petit-Rhône fan basinal part. The squared areas indicate the location of maps in figures $8 \mathrm{a}$ and $10 . \mathrm{N}$ is the youngest channel (neochannel); 1 is the channel that was active just before $\mathrm{N}$. Blue lines: location of the MAK-1M survey.

Figure 2: Method to reveal faint topographic variations at the termination of the Petit-Rhône Fan, using SonarScope software. (a): Original 100 m grid PROGRES DTM. (b): Polynomial surface calculated by the software that represent the first order trend (slope) of the bathymetry). (c): Resulting corrected relief map obtained by subtracting (b) from (a). (d): Sunshaded relief map.

804

Figure 3: Main elements of the Quaternary Rhône fan channel network. (a): Successive major avulsions divide the network into several branches called, from upstream to downstream: the Rhône Valley connected upstream to the Petit-Rhône Canyon, the Abandoned Main Channel and the principal channels ( 7 to 1 and neochannel, N). Grey

809 dashed lines are the limits of mass transport deposits (MTD) on both sides of the fan, 810 respectively Western Mass Transport Deposit (WMTD) and Eastern Mass Transport Deposit 811 (EMTD). (b) Groups of channels (grey, speculative boundaries). Successive minor avulsions 812 of each principal channel generate distributives channels. Channels N, 1 and 5 do not show minor avulsions and constitute mono-channel groups. (c): Schematic cross sections

814 illustrating the sedimentary architecture along five transects (location in a and b).

816 Figure 4: Topography of the Petit-Rhône Fan South of the neochannel avulsion nodes 817 ( $\left.\mathrm{n}^{\circ} 15\right)$. (a): Sun-shaded bathymetric map (PROGRES $100 \mathrm{~m}$-grid DTM). Eight groups of 
818 channels (bold lettering 7 to 1 and $\mathrm{N}$ from the oldest to the youngest) made of 1 to 4

819 successive sub-channels ( $d$ to a, from the oldest to the youngest) are identifiable. Yellow and

820 black dots and numbering of avulsion nodes same as in (d). Modified from Gillet et al. (2006).

821 (b): Slope map of the bifurcation area between the neochannel $(\mathrm{N})$ and the Abandoned Main

822 Channel (AMC, 1) (combined PROGRES and MARION DTM). (c): Upfan to downfan serial

823 bathymetric profiles (see locations in a, lines A to G). Grey: salt domes. Red line: course of

824 channel 1. (d): Relative chronology of channels established from bathymetric and seismic

825 analysis. Yellow and black dots refer respectively to main and minor (second, third and fourth

826 order) avulsion nodes. Bold italic numbers are avulsion node numbers. Light grey area to the

827 left refers to channels identified on the bathymetric map (a). White area to the right refers to

828 channels identified either on the relief map (Fig. 10) or by seismic interpretation only (Fig.

829 11).

830

831 Figure 5: Architectural evolution of the Rhône fan. (a): Relative chronology of deposition of

832 channel-levee systems $7(A)$ to $1(G)$ to $N(I)$, from the oldest to the youngest (see Fig. $4 d$ for

833 the chronology of channels). For each map, the active channel is shown as a bold colored

834 line; the preceding channels are thinner. The avulsion nodes are indicated as numbered

835 yellow dots (major avulsions) and black dots (minor avulsions). Black arrows: Direction of

836 channel migrations. The $(\mathrm{H})$ map represents a stop of turbiditic activity during the instability

837 period when the WMTD and EMTD (Western and Eastern Mass Transport Deposit,

838 respectively) were emplaced. V: Valencia valley. P: Palamos valley. S: Sète valley. PLR:

839 Pyrénéo-Languedocian Ridge. (b): Migrations of avulsion nodes through time (relative time

840 scale) illustrated by the evolution of the distance between major (yellow bars) and minor

841 (black bars) and a reference point chosen as the last avulsion node ( $\left.n^{\circ} 15\right)$. Grey area and

842 bold italic numbers are channel groups.

844 Figure 6: Along-thalweg profiles of the Rhône fan channels. (a): Neochannel and older

845 channels $2 \mathrm{c} 1,2 \mathrm{bn}, 2 \mathrm{~b} 1,2 \mathrm{a} 1$ and 1 . See Figs. $4 \mathrm{~d}$ for the numbering of avulsion points. Black 
846 and yellow dots are the positions of avulsion nodes, the yellow ones being the "major" ones

847 (see Fig. 4d). The pink dot is the main knick-point observed on the along channel depth

848 profile of the neofan. Note that the distances of older channels-lobes were measured

849 straightly and are therefore underestimated. (b): Zoom on the neochannel, modified from

850 Jégou (2008).

851

852 Figure 7: Architecture of the channel network feeding the distal lobes. Very high-resolution

853 SBP profiles (see insets for locations). (a): Strike line across the neochannel, modified from

854 Bonnel et al. (2005). (b-c): Strike lines across channels 4b and 3 to 1, PROGRES data (Droz,

855 2003). Location of SBP lines on insets.

856

857 Figure 8: Morphology of the neofan. (a): Shaded bathymetric map. Combined 50 m-grid DTM 858 from CALMAR 1997 (Loubrieu, 1997), MARION 2000 (Berné, 2000) and PROGRES 2003

859 (Droz, 2003) cruises. See location of the figure in Fig. 1b. White lines: location of SBP

860 profiles in figures 7a and 9. Box: location of figure 14a. (b): Interpretative map of a. (c): 3D

861 bathymetric view of the neofan (observed from the southwest). Blue lines (S and $D)$ in (b) are

862 topographic profiles shown in Fig. 14b).

863

864 Figure 9: Very high-resolution SBP seismic profiles crossing the neofan (see Fig. 8a for

865 location). PROGRES data (Droz, 2003). (a): Termination of the neochannel, showing a by-

866 pass area. (b): Area with erosional channels and small scours. (c-d): Area where wedge

867 shaped seismic units dominate ( $d$ is a zoom on a wedged shape unit). Small scours are

868 visible at the NW part of the line c.

869

870 Figure 10: Detailed morphology of the distal part of the Rhône fan. (a) Sun-shaded corrected

871 relief map (see Section 3.1 and figure 2 for the method used to produce this map). The doted

872 lines outline bulges. (b) Interpretation of a. Blue continuous lines: well identified incising

873 channels. Blue dashed lines: inferred channels. Black lines: unconnected channels. Straight 
874 black lines indicate the locations of profiles shown in figures $7 b, 7 c, 11$ and 12. Dashed-

875 dotted box is the position of the maps shown in Figs. 6a and 13.

876

877 Figure 11: Upstream to downstream architectural evolution of seismic units observed under 878 the topographic bulge associated to channel 2b. Very high-resolution SBP seismic profiles, 879 PROGRES data (Droz, 2003), see Fig. 10b for location. Note on b and d the hummocky

880 areas, with symmetrical (S) and asymmetrical (A) lows that evoke scours. Vertical and 881 horizontal scales are the same in a to $d$ and different in zooms of $a, b$ and $d$.

882

883 Figure 12: Stacking pattern of terminal area of channels $2 a$ and $2 b$. (a): Very high-resolution $8843.5 \mathrm{kHz}$ profiles. SARDINIA data (Aslanian et al., 2006). See Fig. 10b for location. (b): Close 885 up of a and its interpretation.

886

887 Figure 13: Slope of channels older than the neofan and their lobate basinward extensions.

888 (a) Topographic profiles of channels $2 \mathrm{c} 1,2 \mathrm{bn}, 2 \mathrm{~b} 1,2 \mathrm{a} 1$ and 1 , indicating the position of the 889 observed scours (S) and unconnected channels (UC). (b) Location of the depth profiles 890 shown in a. Distances do not account for meanders (straight distances) and are measured 891 from the uppermost avulsion node ( $\left.n^{\circ} 14\right)$. Bold italic numbers $(12,13$ and 14$)$ refer to

892 avulsion node numbers indicated as yellow (major avulsion) and black (minor avulsion) dots 893 (see Fig. 4d for the complete numbering of avulsion nodes and Fig. 10a for the location of 894 the map).

895

896 Figure 14: Erosional features observed at the channel terminations. (a) Close up of the 897 bathymetric map of the neochannel mouth (location in Fig. 8a). (b) Topographic profiles 898 (strike line, S and dip line, D, location in a and in Fig. 8d) across the small-scours field. S:

899 symmetrical scours. A: asymmetrical scours. (c): Zoom of the relief map showing hummocky 900 areas at the terminal parts of channels 1 and 2 (location in Fig. 10) and location dip profiles 901 shown in d. (d): Dip topographic profiles (D1 and D2), showing mainly asymmetrical 
902 topographic features, similar to that of the neofan, even if smaller (compare with b, same

903 vertical and horizontal scales).

904

905 Figure 15: Shaded bathymetry of the neofan area (illumination from the East). Compilation of 906 DTM from MARION (Berné, 2000) and PROGRES (Droz, 2003) cruises at a grid spacing of 90750 m. (a): Bathymetry of the neochannel and its termination. (b) Close up of channel-like 908 features associated to semi-circular scarps some $\mathrm{km}$ from the termination of the neochannel; 909 Ch1 to Ch4 are numbered without age inference. (c) Close up of chevron-like features in the 910 distal part of the neofan.

911

912 Figure 16: Detailed topography of channel-like Ch2 downwards its bifurcation from Ch1. (a):

913 MAK-1M mosaic and its interpretation. See location in figure 15b. (b) and (c): MAK-1M

914 profiles (not corrected for navigation) and associated $5 \mathrm{kHz}$ profile at the head (b) and the 915 distal part (c) of Ch2 (location in a). S1 to S4 refer to scour numbers (no chronological 916 inference).

918 Figure 17: Morpho-structural interpretative maps. (a): Synthesis of studied channel-levee 919 systems replaced in the context of the Late Quaternary depositional systems of the Gulf of 920 Lion (see Fig. 1a for legends about depositional systems other than the Petit-Rhône turbidite 921 system) showing the proposed extension of the 3 main morpho-structural domains. Bold 922 numbers refer to groups of channels. Arrows indicate the directions of lateral migration 923 consecutive to avulsions for different hierarchical orders. (b): Chronology of seismic bodies 924 identified in the distal parts of the Rhône fan, established from overlapping relationships 925 observed on SBP profiles. (c): Main dimensions measured and reported in Tables 1 and 2. 926 Lengths are measured straightly and therefore are underestimated. TL and TW: total length 927 (measured from the Petit-Rhône canyon head) and maximum total width of the fan, 928 respectively; L1, L2 and L3: length of domains 1 (measured from the avulsion node from 
929 which the channels are issued), 2 and 3, respectively; W1, W2 and W3: maximum width of

930 domains 1, 2 and 3, respectively.

932 Figure 18: Morphometric analysis of domains 3 of the morphological bulges $2 \mathrm{bn}, 2 \mathrm{~b} 1,2 \mathrm{a} 1,1$ 933 and N. (a): Log-Log plot of the maximum width to maximum thickness. (b): Log-Log plot of

934 the length/width (aspect ratio) to maximum thickness/maximum area. Inspired from Prélat et 935 al. (2010). See Supplementary Material for details of measurements. Due to incomplete 936 coverage, maximum width and maximum area for domain 3 of bulge 1 are minimum.

938 Figure 19: Proposed formation of sinuous channel-levee systems on a very low gradient 939 seafloor, ultimately leading to basinwards propagation of the channel. (A) Conceptual 940 evolution of the scours field during progressive flow containment. (B) Application to the 941 Rhône neofan.(1 to 3): scour controlled initiation of a sinuous channel (based on 942 observations in the neofan, see Figs. 15, 16). (4 and 5): hypothesized further evolution 943 towards a sinuous channel-levee system (4) that could prograde basinwards by connection 944 with the previous neochannel mouth (5). The box inside (5) locates sketches 1 to 4 . (C) 945 Evolution through time of the neochannel mouth (CM 1 and CM 2) and associated scour 946 fields (CLTZ 1 and CLTZ 2), showing a possible next CM (if the neofan was not abandoned 947 after CM2).

948

\section{TABLE CAPTIONS}

950 Table 1: Architecture and known ages of the Rhône fan and CMLs (neofan and older CMLs $9512 \mathrm{c}$ to 1). See Fig. 17b for explanations of measured dimensions TW and TL, D14 and D15.

953 Table 2: Sizes of the Rhône CMLs (systems 2c to 1 and neofan) and of the erosional 954 features (scours and unconnected channels) and wedge-shaped seismic units. See Fig. 17b 955 for explanations of measured dimensions $\mathrm{W}$ and $\mathrm{L}$. 


\section{REFERENCES}

957 Amy, L. A., 2019. A review of producing fields inferred to have upslope stratigraphically 958 trapped turbidite reservoirs: Trapping styles (pure and combined), pinch-out formation, and 959 depositional setting. Aapg Bulletin, 103 (12): 2861-2889. DOI: 10.1306/02251917408.

960 Aslanian, D., Geli, L. and Olivet, J. L., 2006. SARDINIA cruise, RV L'Atalante. DOI:

$961 \quad 10.17600 / 6010150$.

962 Babonneau, N., Savoye, B., Cremer, M. and Klein, B., 2002. Morphology and architecture of 963 the present canyon and channel system of the Zaire deep-sea fan. Marine and Petroleum 964 Geology, 19 (4): 445-467. DOI: 10.1016/S0264-8172(02)00009-0.

965 Badhani, S., Cattaneo, A., Dennielou, B., Leroux, E., Colin, F., Thomas, Y., Jouet, G., 966 Rabineau, M. and Droz, L., 2020. Morphology of retrogressive failures in the Eastern Rhone 967 Interfluve during the Last Glacial Maximum (Gulf of Lions, Western Mediterranean).

968 Geomorphology, 351: 106894. DOI: 10.1016/j.geomorph.2019.106894.

969 Bassetti, M. A., Berne, S., Jouet, G., Taviani, M., Dennielou, B., Flores, J. A., Gaillot, A., 970 Gelfort, R., Lafuerza, S. and Sultan, N., 2008. The 100-ka and rapid sea level changes 971 recorded by prograding shelf sand bodies in the Gulf of Lions (western Mediterranean Sea).

972 Geochemistry Geophysics Geosystems, 9. DOI: 10.1029/2007gc001854.

973 Bassetti, M. A., Jouet, G., Dufois, F., Berne, S., Rabineau, M. and Taviani, M., 2006. Sand 974 bodies at the shelf edge in the Gulf of Lions (Western Mediterranean): Deglacial history and 975 modern processes. Marine Geology, 234 (1-4): 93-109. DOI: 10.1016/j.margeo.2006.09.010. 976 Baztan, J., Berne, S., Olivet, J. L., Rabineau, M., Aslanian, D., Gaudin, A., Rehault, J. P. and 977 Canals, M., 2005. Axial incision: The key to understand submarine canyon evolution (in the 978 western Gulf of Lion). Marine and Petroleum Geology, 22 (6-7): 805-826. DOI:

979 10.1016/j.marpetgeo.2005.03.011.

980 Bellaiche, G., Coutellier, V. and Droz, L., 1986. Seismic evidence of widespread mass 981 transport deposits in the Rhône deep-sea fan: Their role in the fan construction. Marine 982 Geology, 89: 259-268. DOI: 10.1016/0025-3227(86)90076-9. 
Berné, S., 2000. MARION cruise, RV Le Suroît. DOI: 10.17600/20110.

984 Berné, S., Aloïsi, J. C., Baztan, J., Dennielou, B., Droz, L., dos Reis, A. T., Lofi, J., Méar, Y.

985

986

987

988

989

990

991

992

993

994

995

996

997

998

999

1000

1001

1002

1003

1004

1005

1006

1007

1008

1009 and Rabineau, M., 2002a. Notice de la carte morpho-bathymétrique du Golfe du Lion. 48 pp. Berné, S., Carré, D., Loubrieu, B., Mazé, J.-P. and Normand, A., 2001. Carte morphobathymétrique du Golfe du Lion à l'échelle 1/100 000 ème. Brest, IFREMER et Région Languedoc Roussillon.

Berné, S., Satra, C., Aloïsi, J. C., Baztan, J., Dennielou, B., Droz, L., Dos Reis, A. T., Lofi, J., Méar, Y. and Rabineau, M., 2002b. Carte morpho-bathymétrique du Golfe du Lion, notice explicative. Ifremer, Brest.

Bonnel, C., Dennielou, B., Droz, L., Mulder, T. and Berné, S., 2005. Architecture and depositional pattern of the Rhône Neofan and recent gravity activity in the Gulf of Lions (Western Mediterranean). Marine and Petroleum Geology, 22 (6-7): 827-843. DOI: 10.1016/j.marpetgeo.2005.03.003.

Brooks, H. L., Hodgson, D. M., Brunt, R. L., Peakall, J., Hofstra, M. and Flint, S. S., 2018. Deep-water channel-lobe transition zone dynamics: Processes and depositional architecture, an example from the Karoo Basin, South Africa. Geological Society of America Bulletin, 130 (9-10): 1723-1746. DOI: 10.1130/b31714.1.

Canals, M., Puig, P., Durrieu de Madron, X., Heussner, S., Palanques, A. and Fabres, J., 2006. Flushing submarine canyons. Nature, 444 (7117): 354-355. DOI: 10.1038/nature05271.

Carvajal, C., Paull, C. K., Caress, D. W., Fildani, A., Lundsten, E., Anderson, K., Maier, K. L., McGann, M., Gwiazda, R. and Herguera, J. C., 2017. Unraveling the channel-lobe Transition zone with high-resolution AUV bathymetry: Navy Fan, offshore Baja California, Mexico Journal of Sedimentary Research, 87 (10): 1049-1059. DOI: 10.2110/jsr.2017.58.

Covault, J. A., Kostic, S., Paull, C. K., Ryan, H. F. and Fildani, A., 2014. Submarine channel initiation, filling and maintenance from sea-floor geomorphology and morphodynamic modelling of cyclic steps. Sedimentology, 61 (4): 1031-1054. DOI: 10.1111/sed.12084. 
1010 de Leeuw, J., Eggenhuisen, J. T. and Cartigny, M. J. B., 2016. Morphodynamics of

1011 submarine channel inception revealed by new experimental approach. Nature

1012 Communications, 7:10886. DOI: 10.1038/ncomms10886.

1013 Dennielou, B., Droz, L., Babonneau, N., Jacq, C., Bonnel, C., Picot, M., Le Saout, M., Saout, 1014 Y., Bez, M., Savoye, B., Olu, K. and Rabouille, C., 2017. Morphology, structure, composition

1015 and build-up processes of the active channel-mouth lobe complex of the Congo deep-sea fan

1016 with inputs from remotely operated underwater vehicle (ROV) multibeam and video surveys.

1017 Deep-Sea Research Part II-Topical Studies in Oceanography, 142: 25-49. DOI:

$1018 \quad$ 10.1016/j.dsr2.2017.03.010.

1019 Dennielou, B., Jallet, L., Sultan, N., Jouet, G., Giresse, P., Voisset, M. and Berné, S., 2009.

1020 Post-glacial persistence of turbiditic activity within the Rhone deep-sea turbidite system (Gulf

1021 of Lions, Western Mediterranean): Linking the outer shelf and the basin sedimentary records.

1022 Marine Geology, 257 (1-4): 65-86. DOI: 10.1016/j.margeo.2008.10.013.

1023 Dennielou, B., Jegou, I., Droz, L., Jouet, G., Cattaneo, A., Aslanian, D., Berné, S., Loubrieu,

1024 B., Rabineau, M., Sultan, N. and Bermell, S., 2019. Major modification of sediment routing by 1025 a giant Mass Transport Deposit in the Gulf of Lions (Western Mediterranean). Marine 1026 Geology, 411: 1-20. DOI: 10.1016/j.margeo.2019.01.011.

1027 Deptuck, M. E., Piper, D. J. W., Savoye, B. and Gervais, A., 2008. Dimensions and 1028 architecture of late Pleistocene submarine lobes off the northern margin of East Corsica.

1029 Sedimentology, 55 (4): 869-898. DOI: 10.1111/j.1365-3091.2007.00926.x.

1030 Deptuck, M. E., Steffens, G. S., Barton, M. and Pirmez, C., 2003. Architecture and evolution 1031 of upper fan channel-belts on the Niger Delta slope and in the Arabian Sea. Marine And 1032 Petroleum Geology, 20 (6-8): 649-676.

1033 Dorrell, R. M., Peakall, J., Sumner, E. J., Parsons, D. R., Darby, S. E., Wynn, R. B., Özsoy, 1034 E. and Tezcan, D., 2016. Flow dynamics and mixing processes in hydraulic jump arrays: 1035 Implications for channel-lobe transition zones. Marine Geology, 381: 181-193. DOI: $1036 \quad$ 10.1016/j.margeo.2016.09.009. 
1037 dos Reis, A. T., 2001. La tectonique salifère et son influence sur l'architecture sédimentaire 1038 quaternaire de la marge du Golfe du Lion, Méditerranée Occidentale - 2 Volumes. PhD 1039 Thesis, Paris 6 University. 373 pp.

1040 dos Reis, A. T., Gorini, C. and Mauffret, A., 2005. Implications of salt-sediment interactions 1041 on the architecture of the Gulf of Lions deep-water sedimentary systems-western

1042 Mediterranean Sea. Marine and Petroleum Geology, 22 (6-7): 713-746. DOI:

$1043 \quad$ 10.1016/j.marpetgeo.2005.03.006.

1044 Droz, L., 2003. PROGRES cruise, RV Le Suroît. DOI: 10.17600/3020080.

1045 Droz, L. and Bellaiche, G., 1985. Rhone Deep-Sea Fan: morphostructure and growth pattern. 1046 American Association of Petroleum Geologists Bulletin, 69: 460-479.

1047 Droz, L., dos Reis, A. T., Rabineau, M., Berné, S. and Bellaiche, G., 2006. Quaternary 1048 turbidite systems on the northern margins of the Balearic Basin (Western Mediterranean): a 1049 synthesis. Geo-Marine Letters, 26 (6): 347-359. DOI: 10.1007/s00367-006-0044-0.

1050 Droz, L., Kergoat, R., Cochonat, P. and Berné, S., 2001. Recent sedimentary events in the 1051 western Gulf of Lions (Western Mediterranean). Marine Geology, 176 (1-4): 23-37. DOI:

$1052 \quad 10.1016 / \mathrm{s} 0025-3227(01) 00147-5$.

1053 Droz, L., Marsset, T., Ondreas, H., Lopez, M., Savoye, B. and Spy-Anderson, F. L., 2003a.

1054 Architecture of an active mud-rich turbidite system: The Zaire Fan (Congo-Angola margin

1055 southeast Atlantic): Results from ZaiAngo 1 and 2 cruises. AAPG Bulletin, 87 (7): 1145-1168.

1056 DOI: 10.1306/03070300013.

1057 Droz, L., Rabineau, M. and Progres Shipboard Scientific Party, 2003b. Interrelationships 1058 between the sedimentary systems in the Western Mediterranean (Gulf of Lions and Balearic 1059 Abyssal Plain): preliminary results from PROGRES cruise (EUROSTRATAFORM 1060 programme). Ocean Margin Research Conference, OMARC, Paris.

1061 Elliott, T., 2000. Megaflute erosion surfaces and the initiation of turbidite channels. Geology, 106228 (2): 119-122. DOI: 10.1130/0091-7613(2000)28<119:MESATI>2.0.CO;2.

1063 Fierens, R., Droz, L., Toucanne, S., Raisson, F., Jouet, G., Babonneau, N., Miramontes, E., 1064 Landurain, S. and Jorry, S. J., 2019. Late Quaternary geomorphology and sedimentary 
1065 processes in the Zambezi turbidite system (Mozambique Channel). Geomorphology, 334: 1-

1066 28. DOI: 10.1016/j.geomorph.2019.02.033.

1067 Fildani, A., Hubbard, S. M., Covault, J. A., Maier, K. L., Romans, B. W., Traer, M. and

1068 Rowland, J. C., 2013. Erosion at inception of deep-sea channels. Marine and Petroleum

1069 Geology, 41: 48-61. DOI: 10.1016/j.marpetgeo.2012.03.006.

1070 Fildani, A. and Normark, W. R., 2004. Late Quaternary evolution of channel and lobe

1071 complexes of Monterey Fan. Marine Geology, 206 (1-4): 199-223. DOI:

1072 10.1016/j.margeo.2004.03.001.

1073 Fildani, A., Normark, W. R., Kostic, S. and Parker, G., 2006. Channel formation by flow

1074 stripping: large-scale scour features along the Monterey East Channel and their relation to

1075 sediment waves. Sedimentology, 53: 1265-1287. DOI: 10.1111/j.1365-3091.2006.00812.x.

1076 Flood, R. C., Manley, P. L., Kowsmann, K. O., Appi, C. J. and Pirmez, C., 1991. Seismic

1077 facies and late Quaternary growth of Amazon submarine fan. Seismic Facies and

1078 Sedimentary Processes of Submarine Fans and Turbidite Systems. P. Weimer and M. H.

1079 Link. NewYork, Springer-Verlag: 415-434.

1080 Gales, J. A., Talling, P. J., Cartigny, M. J. B., Clarke, J. H., Lintern, G., Stacey, C. and Clare,

1081 M. A., 2019. What controls submarine channel development and the morphology of deltas

1082 entering deep-water fjords? Earth Surface Processes and Landforms, 44 (2): 535-551. DOI:

$1083 \quad 10.1002 /$ esp.4515.

1084 Gaudin, M., Berné, S., Jouanneau, J.-M., Palanques, A., Puig, P., Mulder, T., Cirac, P.,

1085 Rabineau, M. and Imbert, P., 2006. Massive sand beds attributed to deposition by dense

1086 water cascades in the Bourcart canyon head, Gulf of Lions (northwestern Mediterranean

1087 Sea). Marine Geology, 234 (1-4): 111-128. DOI: 10.1016/j.margeo.2006.09.020.

1088 Gaullier, V., Antonini, E., Benkhelil, J. and Got, H., 1998. Recent gravity-driven sedimentary

1089 bodies in the North-Balearic Basin: geometry and quantification. Comptes Rendus de

1090 I'Académie des Sciences - Series IIA - Earth and Planetary Science, 327 (10): 677-684. DOI:

$1091 \quad 10.1016 / \mathrm{S} 1251-8050(99) 80025-1$. 
1092 Gillet, H., Droz, L., Savoye, B. and Bez, M., 2006. Morphostructure of the channel/levee

1093 complexes and correlative terminal lobes of the Petit-Rhône Fan (Western Mediterranean):

1094 Results from PROGRES cruise (EUROSTRATAFORM Project). European Geosciences

1095 Union General Assembly, Vienna, Austria, 2-7 April 2006.

1096 Girardclos, S., Hilbe, M., Corella, J. P., Loizeau, J.-L., Kremer, K., DelSontro, T., Arantegui,

1097 A., Moscariello, A., Arlaud, F., Akhtman, Y., Anselmetti, F. S. and Lemmin, U., 2012.

1098 Searching the Rhone delta channel in Lake Geneva since François-Alphonse Forel. Archive 1099 des Sciences, 65 (1-2): 103-118.

1100 Guiastrennec-Faugas, L., Gillet, H., Jacinto, R. S., Dennielou, B., Hanquiez, V., Schmidt, S., 1101 Simplet, L. and Rousset, A., 2020. Upstream migrating knickpoints and related sedimentary 1102 processes in a submarine canyon from a rare 20-year morphobathymetric time-lapse 1103 (Capbreton submarine canyon, Bay of Biscay, France). Marine Geology, 423: 6143-6143.

1104 Heijnen, M. S., Clare, M. A., Cartigny, M. J. B., Talling, P. J., Hage, S., Lintern, D. G., 1105 Stacey, C., Parsons, D. R., Simmons, S. M., Chen, Y., Sumner, E. J., Dix, J. K. and Hughes 1106 Clarke, J. E., 2020. Rapidly-migrating and internally-generated knickpoints can control 1107 submarine channel evolution. Nature Communications, 11 (1): 3129. DOI: 10.1038/s414671108 020-16861-x.

1109 Hodgson, D. M., Kane, I. A., Flint, S. S., Brunt, R. L. and Ortiz-Karpf, A., 2016. Time-

1110 transgessive confinement on the slope and the progradation of basin-floor fans: implications

1111 for the sequence stratigraphy of deep-water deposits. Journal of Sedimentary Research, 86 1112 (2): 73-86. DOI: 10.2110/jsr.2016.3.

1113 Hofstra, M., Hodgson, D. M., Peakall, J. and Flint, S. S., 2015. Giant scour-fills in ancient

1114 channel-lobe transition zones: Formative processes and depositional architecture.

1115 Sedimentary Geology, 329: 98-114. DOI: 10.1016/j.sedgeo.2015.09.004.

1116 Jallet, L. and Giresse, P., 2005. Construction of the Pyreneo-Languedocian Sedimentary

1117 Ridge and associated sediment waves in the deep western Gulf of Lions (Western

1118 Mediterranean). Marine and Petroleum Geology, 22 (6-7): 865-888. DOI:

1119 10.1016/j.marpetgeo.2005.03.008. 
1120 Jégou, I., 2008. Etude de la transition chenal-levées lobes dans les systèmes turbiditiques

1121 récents. Application à l'éventail turbiditique de l'Amazone et au Néofan du Petit-Rhône. PhD

1122 Thesis, Brest University (UBO). 350 pp.

1123 Jégou, I., Savoye, B., Pirmez, C. and Droz, L., 2008. Channel-mouth lobe complex of the

1124 recent Amazon Fan: The missing piece. Marine Geology, 252: 62-77. DOI:

1125 10.1016/j.margeo.2008.03.004.

1126 Kane, I. A., McCaffrey, W. D. and Martinsen, O. J., 2009. Allogenic vs. autogenic controlson

1127 Megaflute Formation. Journal of Sedimentary Research, 79 (9-10): 643-651. DOI:

$1128 \quad 10.2110 /$ jsr.2009.072.

1129 Kenyon, N., Ivanov, M. K., Akhmetzhanov, A. M. and Kozlova, E. V., 2006. Interdisciplinary

1130 geoscience studies of the Gulf of Cadiz and Western Mediterranean basins. Preliminary

1131 results of investigations during the TTR-14 cruise of RV Professor Logachev July-

1132 September, 2004. United Nations Educational, Scientific and Cultural Organisation

1133 (UNESCO). Intergovernmental Oceanographic Commission.

1134 Kenyon, N. H., Klaucke, I., Millington, J. and Ivanov, M. K., 2002. Sandy submarine canyon-

1135 mouth lobes on the western margin of Corsica and Sardinia, Mediterranean Sea. Marine

1136 Geology, 184 (1-2): 69-84. DOI: 10.1016/S0025-3227(01)00282-1.

1137 Kenyon, N. H., Millington, J., Droz, L. and Ivanov, M. K., 1995. Scour holes in a channel-lobe

1138 transition zone on the Rhône cone. Atlas of Deep-Water Environments: Architectural Styles

1139 in Turbidite Systems. K. T. Pickering, R. N. Hiscott, N. H. Kenyon, F. R. Lucchi and R. D. A.

1140 Smith. London, Chapman and Hall: 212-215.

1141 Klaucke, I., Masson, D. G., Kenyon, N. H. and Gardner, J. V., 2004. Sedimentary processes

1142 of the lower Monterey Fan channel and channel-mouth lobe. Marine Geology, 206 (1-4): 181-

1143 198. DOI: 10.1016/j.margeo.2004.02.006.

1144 Kolla, V., 2007. A review of sinuous channel avulsion patterns in some major deep-sea fans

1145 and factors controlling them. Marine and Petroleum Geology, 24 (6-9): 450-469.

1146 Komar, P. D., 1971. Hydraulic jumps in turbidity currents. Geological Society of America

1147 Bulletin, 82: 1477-1488. 
1148 Labeyrie, L., Jansen, E. and Cortijo, E., 2003. MD 114-Images V à bord du Marion Dufresne.

1149 Institut polaire français Paul-Emile Victor. ISBN: 978-2-910180-29-4.

1150 Lastras, G., Acosta, J., Munoz, A. and Canals, M., 2011. Submarine canyon formation and 1151 evolution in the Argentine Continental Margin between 44 degrees 30 ' $\mathrm{S}$ and 48 degrees S.

1152 Geomorphology, 128 (3-4): 116-136. DOI: 10.1016/j.geomorph.2010.12.027.

1153 Lastras, G., Canals, M., Amblas, D., Ivanov, M., Dennielou, B., Droz, L. and Akhmetzhanov, 1154 A., 2006. Eivissa slides, western Mediterranean Sea: morphology and processes. Geo-

1155 Marine Letters, 26 (4): 225-233. DOI: 10.1007/s00367-006-0032-4.

1156 Lastras, G., Canals, M., Urgeles, R., De Batist, M., Calafat, A. M. and Casamor, J. L., 2004.

1157 Characterisation of the recent BIG'95 debris flow deposit on the Ebro margin, Western

1158 Mediterranean Sea, after a variety of seismic reflection data. Marine Geology, 213 (1-4): 235-

1159 255. DOI: 10.1016/j.margeo.2004.10.008.

1160 Leroux, E., 2012. Quantification des flux sédimentaires et de la subsidence du bassin

1161 provençal. PhD Thesis, Brest University. 445 pp.

1162 Leroux, E., Rabineau, M., Aslanian, D., Gorini, C., Molliex, S., Bache, F., Robin, C., Droz, L.,

1163 Moulin, M., Poort, J., Rubino, J. L. and Suc, J. P., 2017. High-resolution evolution of

1164 terrigenous sediment yields in the Provence Basin during the last $6 \mathrm{Ma}$ : relation with climate

1165 and tectonics. Basin Research, 29 (3): 305-339. DOI: 10.1111/bre.12178.

1166 Leroux, E., Rabineau, M., Aslanian, D., Granjeon, D., Droz, L. and Gorini, C., 2014.

1167 Stratigraphic simulations of the shelf of the Gulf of Lions: testing subsidence rates and sea-

1168 level curves during the Pliocene and Quaternary. Terra Nova, 26 (3): 230-238. DOI:

1169 10.1111/ter.12091.

1170 Lofi, J., Rabineau, M., Gorini, C., Berne, S., Clauzon, G., De Clarens, P., Dos Reis, A. T.,

1171 Mountain, G. S., Ryan, W. B. F., Steckler, M. S. and Fouchet, C., 2003. Plio-Quaternary

1172 prograding clinoform wedges of the western Gulf of Lion continental margin (NW

1173 Mediterranean) after the Messinian Salinity Crisis. Marine Geology, 198 (3-4): 289-+. DOI:

1174 10.1016/s0025-3227(03)00120-8. 
1175 Lombo-Tombo, S., Dennielou, B., Berne, S., Bassetti, M. A., Toucanne, S., Jorry, S. J.,

1176 Jouet, G. and Fontanier, C., 2015. Sea-level control on turbidite activity in the Rhone canyon

1177 and the upper fan during the Last Glacial Maximum and Early deglacial. Sedimentary

1178 Geology, 323: 148-166. DOI: 10.1016/j.sedgeo.2015.04.009.

1179 Lonsdale, P. L. and Hollister, C. D., 1979. Cut-offs at an abyssal meander south of Iceland.

1180 Geology (7): 597-601. DOI: 10.1130/0091-7613(1979)7<597:CAAAMS>2.0.CO;2.

1181 Lopez, M., 2001. Architecture and depositional pattern of the Quaternary deep-sea fan of the

1182 Amazon. Marine and Petroleum Geology, 18 (4): 479-486. DOI: 10.1016/S0264-

$11838172(00) 00071-4$.

1184 Loubrieu, B., 1997. CALMAR97 cruise, RV L'Atalante.

1185 Macdonald, H. A., Wynn, R. B., Huvenne, V. A. I., Peakall, J., Masson, D. G., Weaver, P. P.

1186 E. and McPhail, S. D., 2011. New insights into the morphology, fill, and remarkable longevity

1187 (> 0.2 m.y.) of modern deep-water erosional scours along the northeast Atlantic margin.

1188 Geosphere, 7 (4): 845-867. DOI: 10.1130/GES00611.1.

1189 Maier, K. L., Fildani, A., Paull, C. K., Graham, S. A., McHargue, T. R., Caress, D. W. and

1190 McGann, M., 2011. The elusive character of discontinuous deep-water channels: New

1191 insights from Lucia Chica channel system, offshore California. Geology, 39 (4): 327-330.

1192 DOI: 10.1130/G31589.1.

1193 Maier, K. L., Paull, C. K., Caress, D. W., Anderson, K., Nieminski, N. M., Lundsten, E., Erwin,

1194 B. E., Gwiazda, R. and Fildani, A., 2020. SUBMARINE-FAN DEVELOPMENT REVEALED

1195 BY INTEGRATED HIGH-RESOLUTION DATASETS FROM LA JOLLA FAN, OFFSHORE

1196 CALIFORNIA, USA. Journal of Sedimentary Research, 90 (5): 468-479. DOI:

$1197 \quad$ 10.2110/jsr.2020.22.

1198 Mansor, S., 2009. Avulsion process in turbidite sytems: Stratigraphic and lithologic records.

1199 Application to the Amazon and Zaire turbidite systems. PhD Thesis, Brest University (UBO).

1200225 pp. 
1201 Marsset, T. and Bellec, V., 2002. Late Pleistocene-Holocene deposits of the Rhône inner 1202 continental shelf (France): Detailed mapping and correlation with previous continental and 1203 marine studies. Sedimentology, 49: 255-276. DOI: 10.1046/j.1365-3091.2002.00440.x.

1204 Masson, D. G., Wynn, R. B. and Bett, B. J., 2004. Sedimentary environment of the Faroe-

1205 Shetland and Faroe Bank Channels, north-east Atlantic, and the use of bedforms as

1206 indicators of bottom current velocity in the deep ocean. Sedimentology, 51 (6): 1207-1241.

1207 DOI: 10.1111/j.1365-3091.2004.00668.x.

1208 Menard, H. W., Smith, S. M. and Pratt, R. M., 1965. The Rhone deep-sea Fan. Submarine

1209 Geology and Geophysics (Proceedings of the 17th Symposium of the Colstan Research

1210 Society). W. F. Whittard and R. Bradshaw. London, Buttersworth: 271-285.

1211 Migeon, S., Ducassou, E., Le Gonidec, Y., Rouillard, P., Mascle, J. and Revel-Rolland, M.,

1212 2010. Lobe construction and sand/mud segregation by turbidity currents and debris flows on

1213 the western Nile deep-sea fan (Eastern Mediterranean). Sedimentary Geology, 229 (3): 124-

1214 143. DOI: $10.1016 /$ j.sedgeo.2010.02.011.

1215 Mignard, S., Mulder, T., Martinez, P. and Garlan, T., 2019. The Ogooue Fan (offshore

1216 Gabon): a modern example of deep-sea fan on a complex slope profile. Solid Earth, 10 (3):

1217 851-869. DOI: 10.5194/se-10-851-2019.

1218 Molliex, S., Rabineau, M., Leroux, E., Bourles, D. L., Authemayou, C., Aslanian, D., Chauvet,

1219 F., Civet, F. and Jouet, G., 2016. Multi-approach quantification of denudation rates in the

1220 Gulf of Lion source-to-sink system (SE France). Earth and Planetary science Letters, 444:

1221 101-115. DOI: 10.1016/j.epsl.2016.03.043.

1222 Mulder, T. and Etienne, S., 2010. Lobes in deep-sea turbidite systems: State of the art

1223 Preface. Sedimentary Geology, 229 (3): 75-80. DOI: 10.1016/j.sedgeo.2010.06.011.

1224 Mutti, E. and Normark, W. R., 1987. Comparing examples of modern and ancient turbidite 1225 systems: problems and concepts. Marine Clastic Sedimentology. L. J.K. and Z. G.G. London, 1226 Graham and Trotman: 1-38. 
1227 Normark, W. R., Fildani, A., Kostic, S. and Parker, G., 2005. Large kilometer-scale erosional

1228 depositional bedforms as a result of turbidity-current overflow from the Monterey Channel.

1229 American Association of Petroleum Geologists Annual Convention, Calgary, Canada.

1230 O'Connell, S., McHugh, C. and Ryan, W. B. F., 1995. Unique fan morphology in an

1231 entrenched thalweg channel on the Rhône Fan. Atlas of Deep Water Environments :

1232 Architectural style in turbidite systems. K. T. Pickering, R. N. Hiscott, N. H. Kenyon, F. Ricci

1233 Luchi and R. D. A. Smith. Aberdeen, Chapman \& Hall: 80-83.

1234 O'Connell, S., Normark, W. R., Ryan, W. B. F. and Kenyon, N. H., 1991. An entrenched

1235 thalweg channel on the Rhône fan : interpretation from a SEABEAM and SEAMARC I

1236 survey. From Shoreline to Abyss: Contributions to Marine Geology in Honor of Francis

1237 Parker Shepard. R. H. Osborne, SEPM Special Publication. 46: 259-270.

1238 Ortiz-Karpf, A., Hodgson, D. M. and McCaffrey, W. D., 2015. The role of mass-transport

1239 complexes in controlling channel avulsion and the subsequent sediment dispersal patterns

1240 on an active margin: The Magdalena Fan, offshore Colombia. Marine and Petroleum

1241 Geology, 64: 58-75. DOI: 10.1016/j.marpetgeo.2015.01.005.

1242 Palanques, A., de Madron, X. D., Puig, P., Fabres, J., Guillen, J., Calafat, A., Canals, M.,

1243 Heussner, S. and Bonnin, J., 2006. Suspended sediment fluxes and transport processes in

1244 the Gulf of Lions submarine canyons. The role of storms and dense water cascading. Marine

1245 Geology, 234 (1-4): 43-61. DOI: 10.1016/j.margeo.2006.09.002.

1246 Palanques, A., Kenyon, N. H., Alonso, B. and Limonov, A., 1995. Erosional and Depositional

1247 Patterns in the Valencia Channel Mouth: An Exemple of a Modern Channel-Lobe Transition

1248 Zone. Marine Geophysical Researches, 17: 503-517. DOI: 10.1007/BF01204341.

1249 Peakall, J., Best, J., Baas, J. H., Hodgson, D. M., Clare, M. A., Talling, P. J., Dorrell, R. M.

1250 and Lee, D. R., 2020. An integrated process-based model of flutes and tool marks in deep-

1251 water environments: Implications for palaeohydraulics, the Bouma sequence and hybrid

1252 event beds. Sedimentology, 67 (4): 1601-1666. DOI: 10.1111/sed.12727. 
1253 Peakall, J., McCaffrey, B. and Kneller, B., 2000. A process model for the evolution,

1254 morphology, and architecture of sinuous submarine channels. Journal of Sedimentary

1255 Research, 70 (3): 434-448.

1256 Picot, M., 2015. Cycles sédimentaires dans le système turbiditique du Congo : nature et

1257 origine. PhD thesis, Brest University (UBO). 368 pp.

1258 Picot, M., Droz, L., Marsset, T., Dennielou, B. and Bez, M., 2016. Controls on turbidite

1259 sedimentation: Insights from a quantitative approach of submarine channel and lobe

1260 architecture (Late Quaternary Congo fan). Marine and Petroleum Geology, 72: 423-446. DOI:

$1261 \quad 10.1016 /$ j.marpetgeo.2016.02.004.

1262 Piper, D. J. W. and Normark, W. R., 2001. Sandy fans - from Amazon to Hueneme and

1263 beyond. American Association of Petroleum Geologist Bulletin, 85 (8): 1407-1438.

1264 Pirmez, C. and Flood, R. D., 1995. Morphology and structure of Amazon Channel.

1265 Proceedings of the Ocean Drilling Program, Initial Reports. R. D. Flood, D. J. W. Piper and A.

1266 Klaus. College Station, TX, Ocean Drilling Program. 155: 23-45.

1267 Pirmez, C., Hiscott, R. N. and Kronen, J. D. J., 1997. Sandy turbidite successions at the base

1268 of channel-levee systems of the Amazon fan revealed by FMS logs and cores: unravelling

1269 the facies architecture of large submarine fans. Proceedings of the Ocean Drilling Program,

1270 Scientific Results. R. D. Flood, D. J. W. Piper, A. Klaus and L. C. Peterson. Austin, Tx, ODP.

1271 155: 7-33.

1272 Pirmez, C. and Imran, J., 2003. Reconstruction of turbidity currents in Amazon Channel.

1273 Marine and Petroleum Geology, 20 (6-8): 823-849.

1274 Pohl, F., Eggenhuisen, J. T., Cartigny, M. J. B., Tilston, M. C., de Leeuw, J. and Hermidas,

1275 N., 2020. The influence of a slope break on turbidite deposits: An experimental investigation.

1276 Marine Geology, 424. DOI: 10.1016/j.margeo.2020.106160.

1277 Pohl, F., Eggenhuisen, J. T., Tilston, M. and Cartigny, M. J. B., 2019. New flow relaxation

1278 mechanism explains scour fields at the end of submarine channels. Nature Communications,

1279 10. DOI: $10.1038 / \mathrm{s} 41467-019-12389-x$. 
1280 Popescu, I., Lericolais, G., Panin, N., Wong, H. K. and Droz, L., 2001. Late Quaternary

1281 channel avulsions on the Danube deep-sea fan, Black Sea. Marine Geology, 179 (1-2): 25-

128237.

1283 Prélat, A., Covault, J. A., Hodgson, D. M., Fildani, A. and Flint, S. S., 2010. Intrinsic controls

1284 on the range of volumes, morphologies, and dimensions of submarine lobes. Sedimentary

1285 Geology, 232 (1-2): 66. DOI: 10.1016/j.sedgeo.2010.09.010.

1286 Prélat, A., Hodgson, D. M. and Flint, S. S., 2009. Evolution, architecture and hierarchy of 1287 distributary deep-water deposits: a high-resolution outcrop investigation from the Permian

1288 Karoo Basin, South Africa. Sedimentology, 56 (7): 2132-U2125. DOI: 10.1111/j.1365-

1289 3091.2009.01073.x.

1290 Rabineau, M., Berne, S., Olivet, J.-L., Aslanian, D., Guillocheau, F. and Joseph, P., 2006.

1291 Paleo sea levels reconsidered from direct observation of paleoshoreline position during

1292 Glacial Maxima (for the last 500,000 yr). Earth and Planetary science Letters, 252 (1-2): 119-

1293 137. DOI: 10.1016/j.epsI.2006.09.033.

1294 Rabineau, M., Leroux, E., Aslanian, D., Bache, F., Gorini, C., Moulin, M., Molliex, S., Droz,

1295 L., dos Reis, A. T., Rubino, J. L., Guillocheau, F. and Olivet, J. L., 2014. Quantifying

1296 subsidence and isostatic readjustment using sedimentary paleomarkers, example from the

1297 Gulf of Lion. Earth and Planetary science Letters, 388: 353-366. DOI:

$1298 \quad$ 10.1016/j.epsl.2013.11.059.

1299 Reading, H. G., 1991. The classification of deep-Sea depositional systems by sediment

1300 caliber and feeder system. Journal of the Geological Society, 148: 427-430. DOI:

$1301 \quad 10.1144 / g s j g s .148 .3 .0427$.

1302 Schwenk, T., Spiess, V., Breitzke, M. and Hubscher, C., 2005. The architecture and

1303 evolution of the Middle Bengal Fan in vicinity of the active channel-levee system imaged by

1304 high-resolution seismic data. Marine and Petroleum Geology, 22 (5): 637-656. DOI:

1305 10.1016/j.marpetgeo.2005.01.007.

1306 Shaw, J., Puig, P. and Han, G. Q., 2013. Megaflutes in a continental shelf setting, Placentia

1307 Bay, Newfoundland. Geomorphology, 189: 12-25. DOI: 10.1016/j.geomorph.2013.01.010. 
1308 Stevenson, C. J., Jackson, C. A. L., Hodgson, D. M., Hubbard, S. M. and Eggenhuisen, J. T., 1309 2015. Deep-water sediment bypass. Journal of Sedimentary Research, 85 (9): 1058-1081. 1310 DOI: 10.2110/jsr.2015.63.

1311 Straub, K. M. and Pyles, D. R., 2012. Quantifying the hierarchical organization of 1312 compensation in submarine fans using surface statistics. Journal of Sedimentary Research, 131382 (11-12): 889-898. DOI: 10.2110/jsr.2012.73.

1314 Sumner, E. J., Talling, P. J., Amy, L. A., Wynn, R. B., Stevenson, C. J. and Frenz, M., 2012. 1315 Facies architecture of individual basin-plain turbidites: Comparison with existing models and 1316 implications for flow processes. Sedimentology, 59 (6): 1850-1887. DOI: 10.1111/j.1365$1317 \quad 3091.2012 .01329 . x$.

1318 Sylvester, Z., Pirmez, C. and Cantelli, A., 2011. A model of submarine channel-levee 1319 evolution based on channel trajectories: Implications for stratigraphic architecture. Marine 1320 and Petroleum Geology, 28 (3): 716-727. DOI: 10.1016/j.marpetgeo.2010.05.012.

1321 Torres, J., 1995. Analyse détaillée du transfert de sédiment du continent vers le bassin : le

1322 Quaternaire terminal au large du Delta du Rhône (Méditerranée nord-occidentale). PhD 1323 Thesis, Brest University (UBO). 353 pp.

1324 Torres, J., Droz, L., Savoye, B., Terentieva, E., Cochonat, P., Kenyon, N. H. and Canals, M., 1325 1997. Deep-sea avulsion and morphosedimentary evolution of the Rhone Fan Valley and 1326 Neofan during the late Quaternary (north-western Mediterranean Sea). Sedimentology, 44 1327 (3): 457-477. DOI: 10.1046/j.1365-3091.1997.d01-36.x.

1328 Twichell, D. C., Kenyon, N. H., Parson, L. M. and McGregor, B. A., 1991. Depositional 1329 Patterns of the Mississippi Fan Surface: Evidence from GLORIA II and High-Resolution 1330 Seismic Profiles. Seismic Facies and Sedimentary Processes of Submarine Fans and 1331 Turbidite Systems. P. Weimer and M. H. Link. New York, NY, Springer: 349-363.

1332 Van der Merwe, W. C., Hodgson, D. M., Brunt, R. L. and Flint, S. S., 2014. Depositional 1333 architecture of sand-attached and sand-detached channel-lobe transition zones on an 1334 exhumed stepped slope mapped over a 2500 km(2) area. Geosphere, 10 (6): 1076-1093. 1335 DOI: $10.1130 /$ ges01035.1. 
1336 Wynn, R. B., Kenyon, N. H., Masson, D. G., Stow, D. A. V. and Weaver, P. P. E., $2002 a$.

1337 Characterization and recognition of deep-water channel-lobe transition zones. American

1338 Association of Petroleum Geologist Bulletin, 86 (8): 1441-1146. DOI: 10.1306/61EEDCC4-

1339 173E-11D7-8645000102C1865D.

1340 Wynn, R. B., Piper, D. J. W. and Gee, M. J. R., 2002b. Generation and migration of coarse-

1341 grained sediment waves in turbidity current channels and channel-lobe transition zones.

1342 Marine Geology, 192 (1-3): 59-78.

1343 Wynn, R. B. and Stow, D. A. V., 2002. Recognition and interpretation of deep-water sediment

1344 waves: implications for palaeoceanography, hydrocarbon exploration and flow process

1345 interpretation. Marine Geology, 192 (1-3): 1-3. DOI: 10.1016/S0025-3227(02)00546-7.

1346 Zhang, L. F., Pan, M. and Wang, H. L., 2017. Deepwater turbidite lobe deposits: A review of

1347 the research frontiers. Acta Geologica Sinica-English Edition, 91 (1): 283-300. DOI:

$1348 \quad 10.1111 / 1755-6724.13078$.

1349 


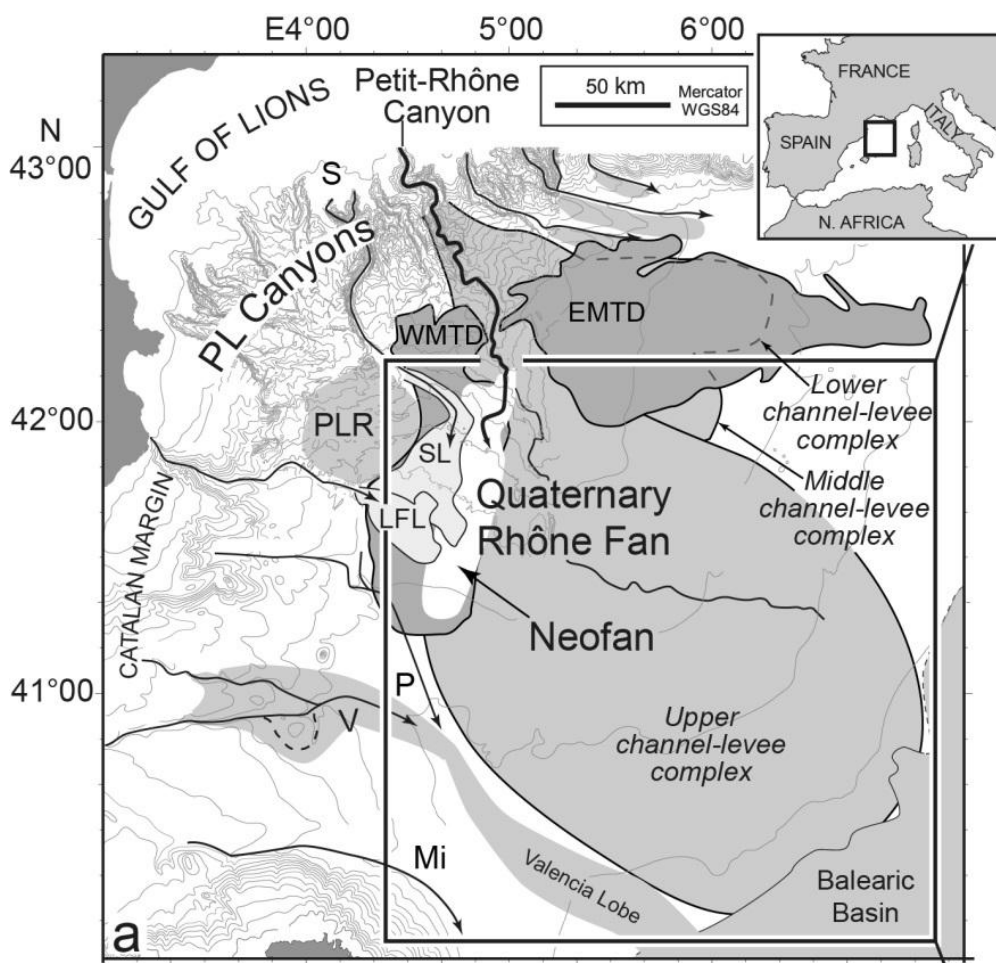

Mi: Minorca Valley; V: Valencia Valley; P. Palamós valley

LFL: La Fonera Lobe; S: Sète Canyon; SL: Sète Lobe

PL: Pyreneo-Languedocian Canyons

PLR: Pyreneo-Languedocian Ridge

WMD: Western Upper Mass-Transport Deposit

EMD: Eastern Upper Mass-Transport Deposit

$\mathrm{N}$ : Neochannel; 1: Last active channel prior to $\mathrm{N}$

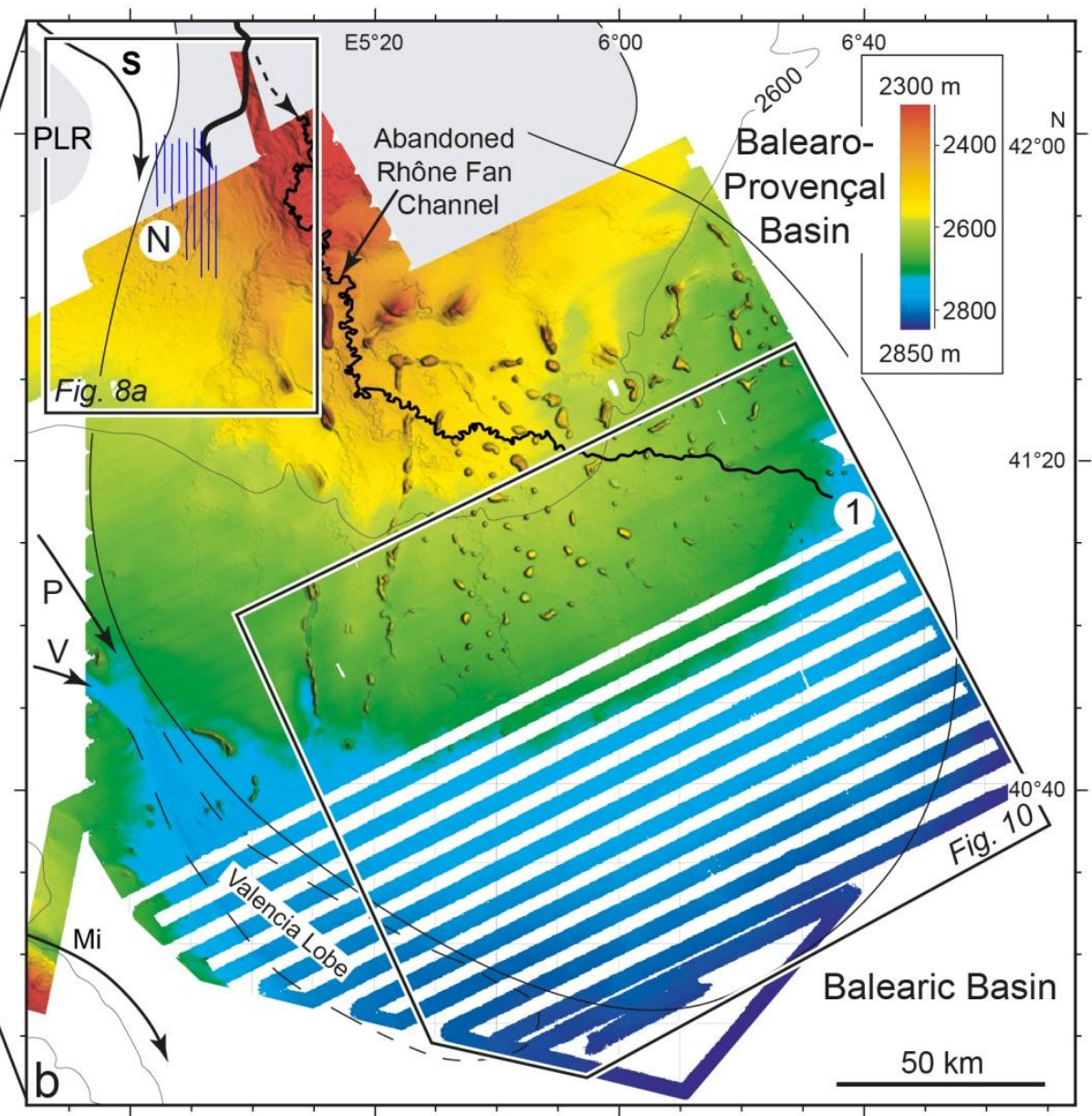

Figure 1 

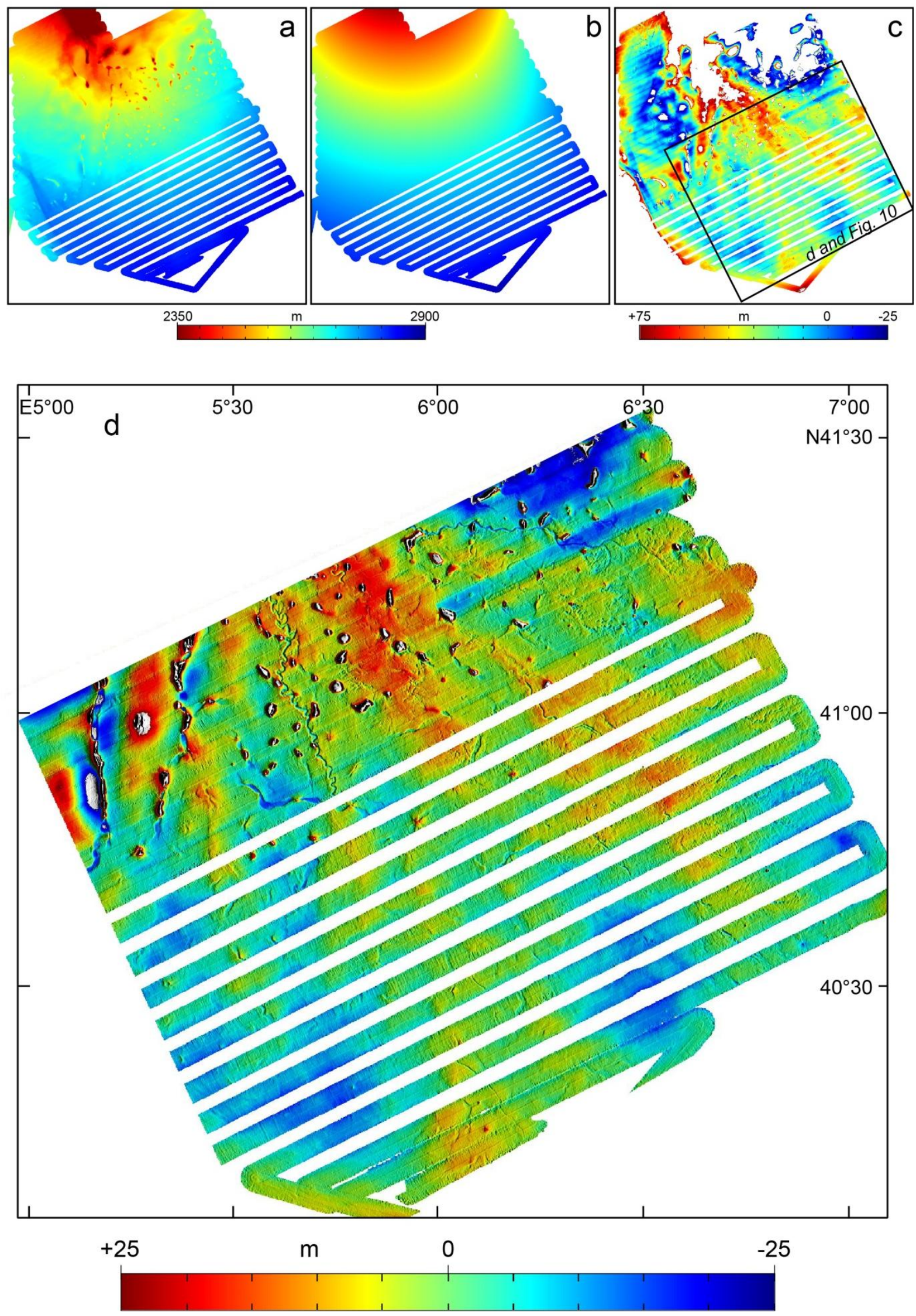

1353 Figure 2 


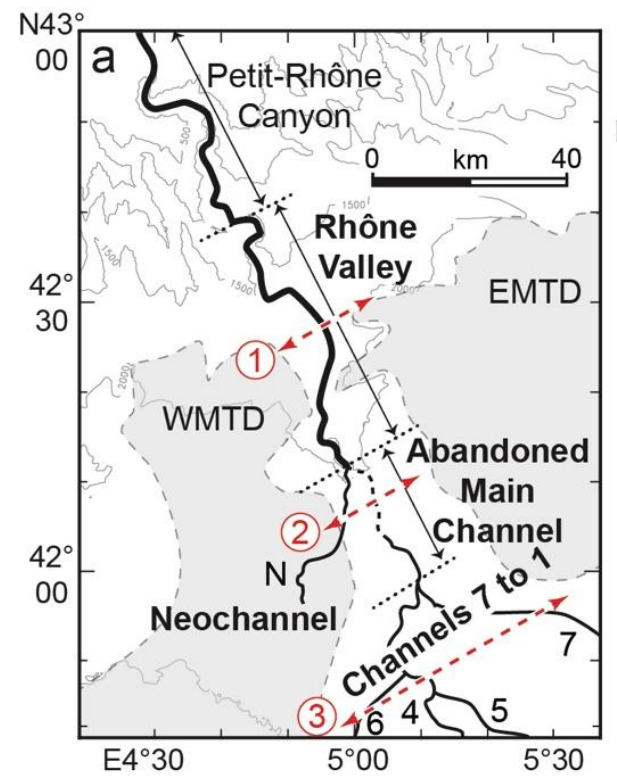

C

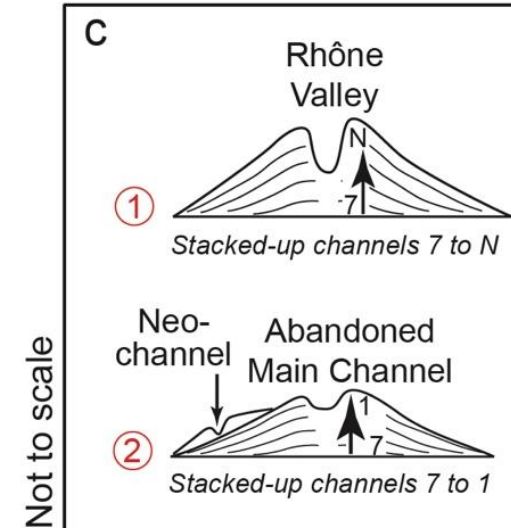

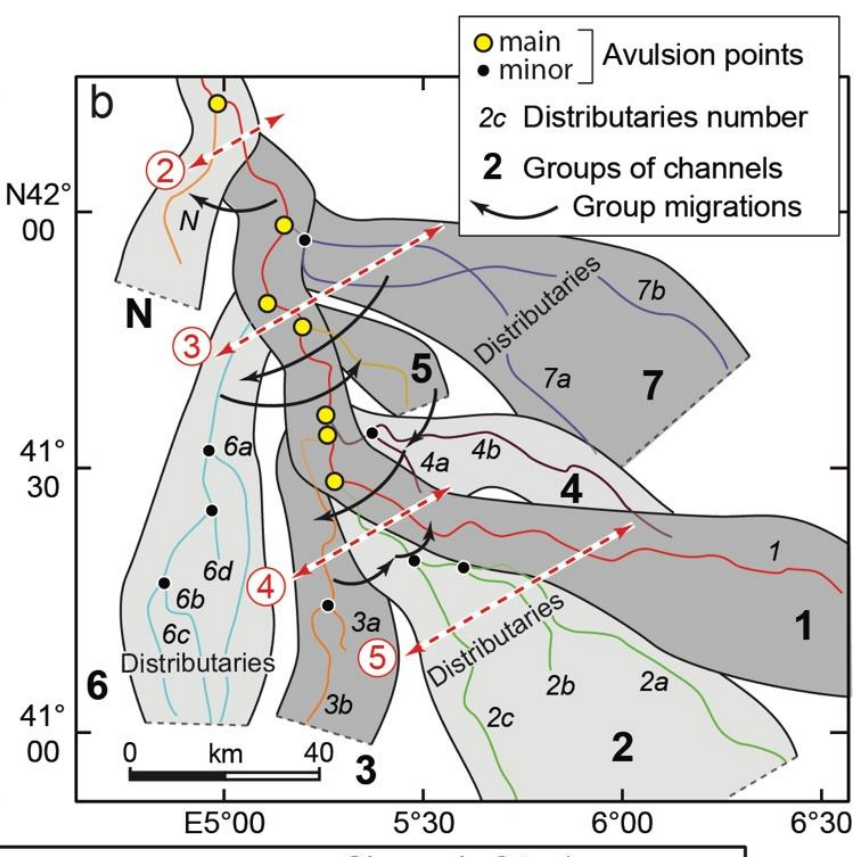

Channels 6 to 1

(and distributaries $7 a$ and $b$ )

(3) 5 to 1



Channels 3 to 1

(4) $\overbrace{\text { Shifted and overlapping channels }}^{3}$

Distributaries 2c to $2 \mathrm{a}$ and Channel 1

(5)

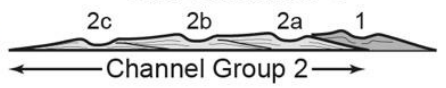

Figure 3 




1357 Figure 4 
(a)
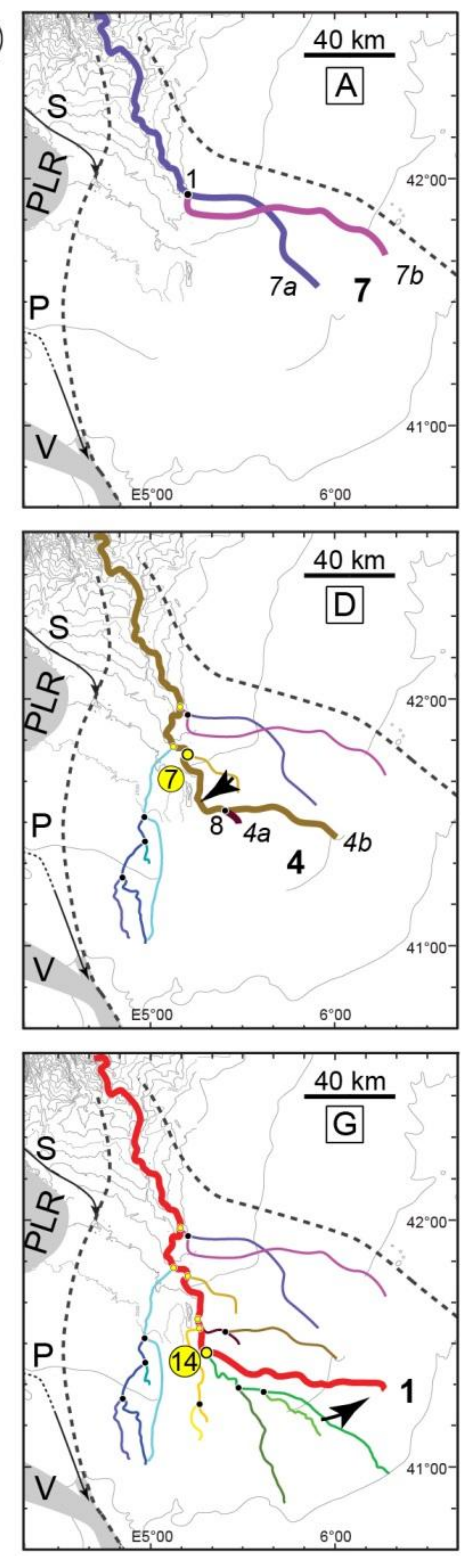

(b)
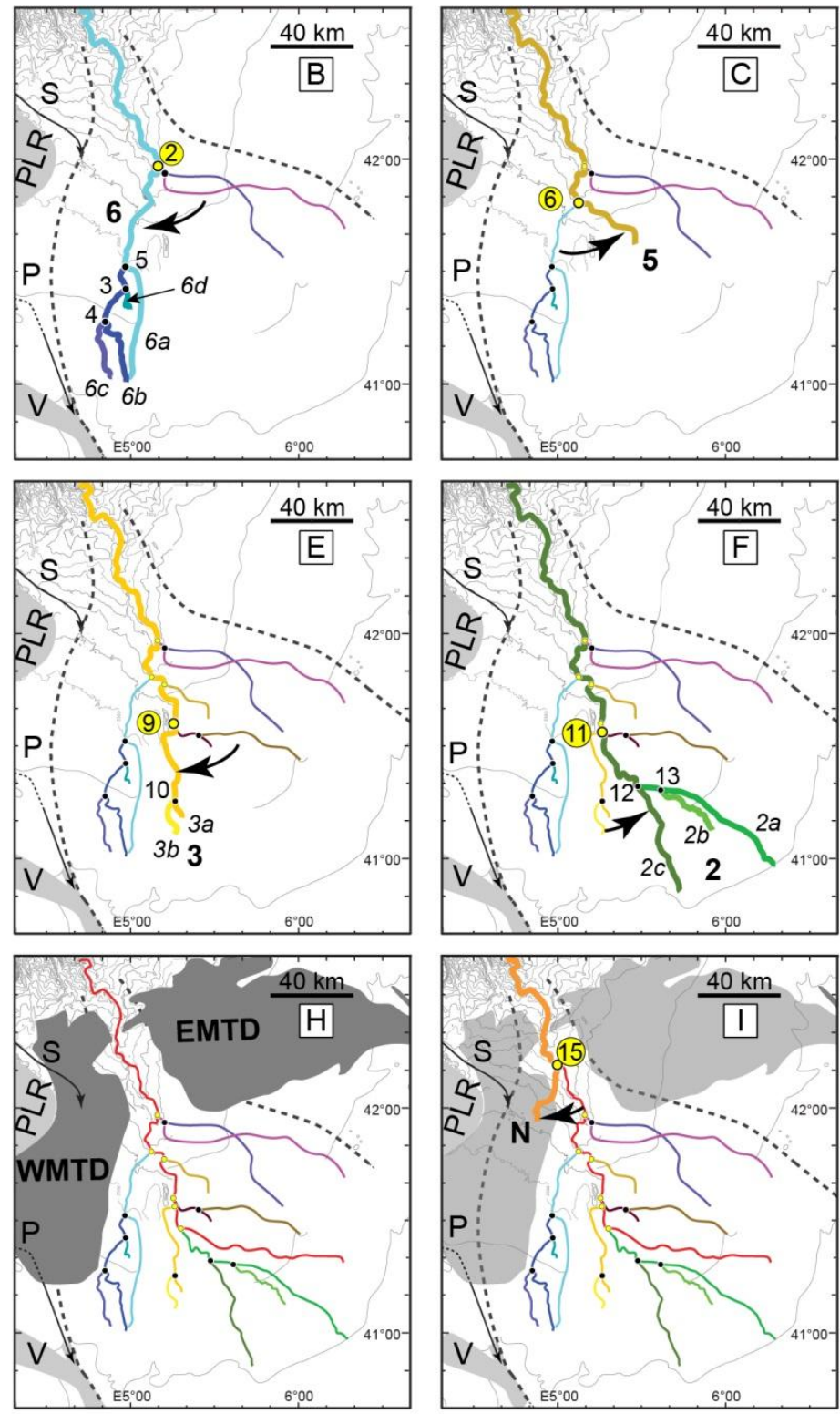

Migration of avulsion nodes

$18.3 \mathrm{cal} . \mathrm{ka}$ Bonnel et al. (2005)

21 ka cal. ka Dennielou et al. (2019)

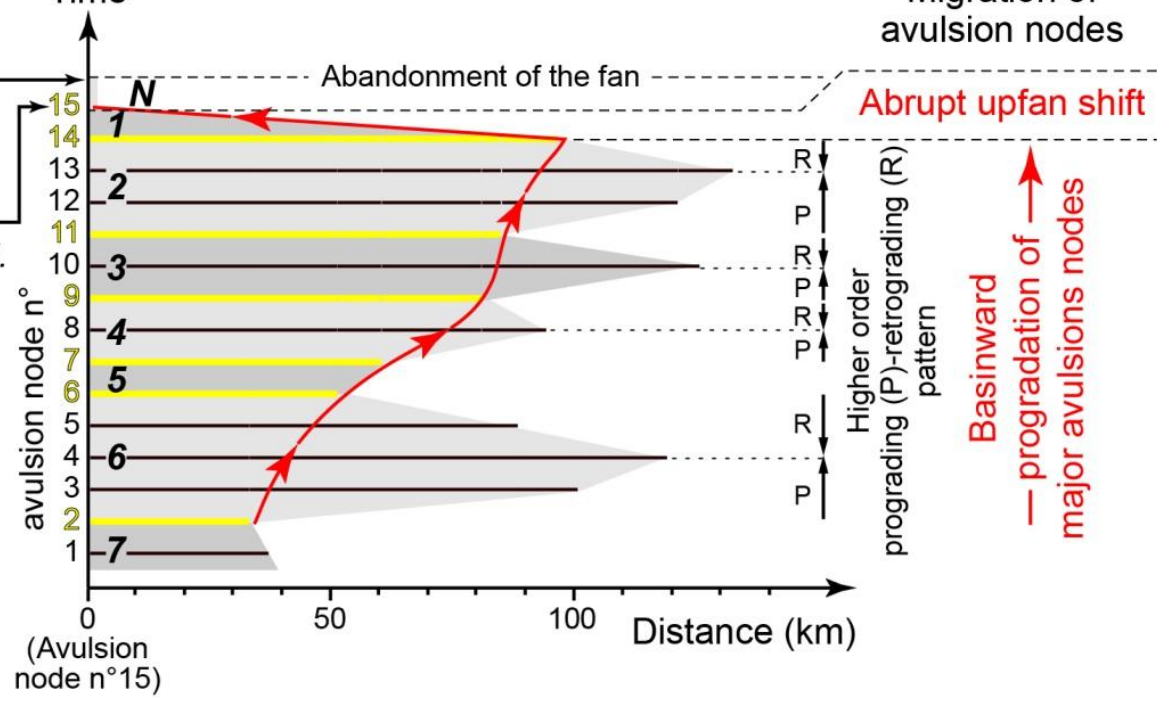

Figure 5 


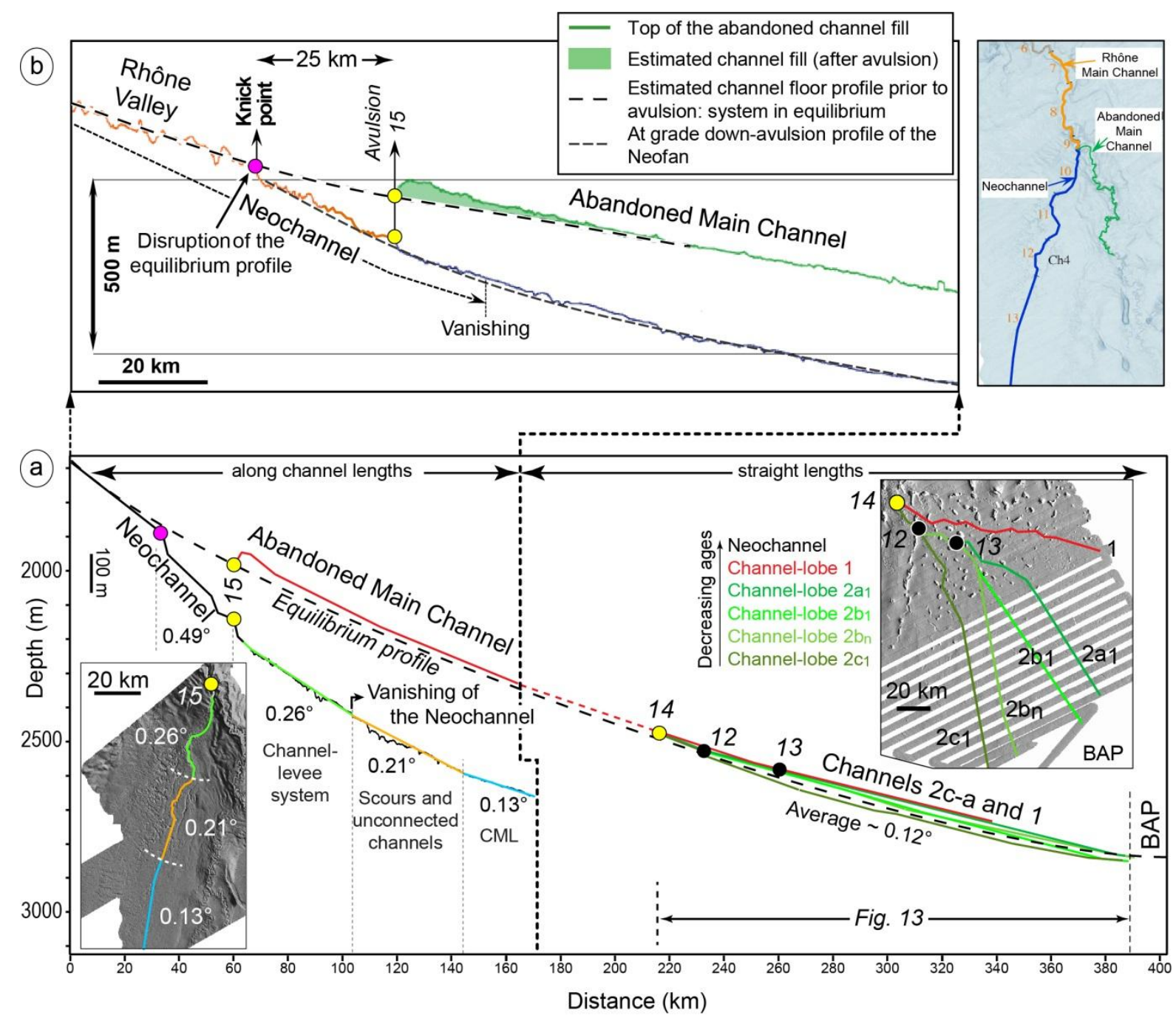

1361 Figure 6 

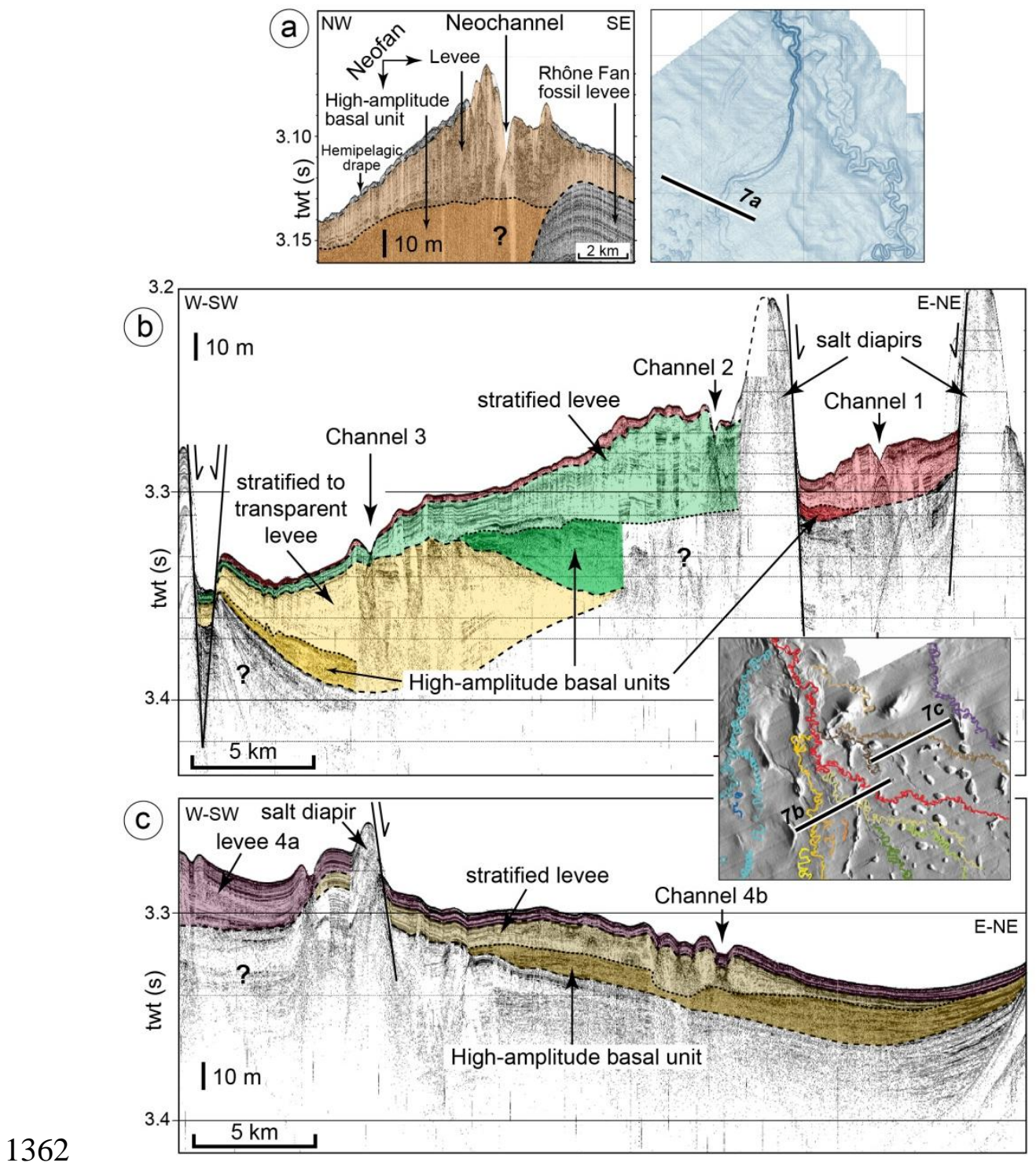

1363 Figure 7 


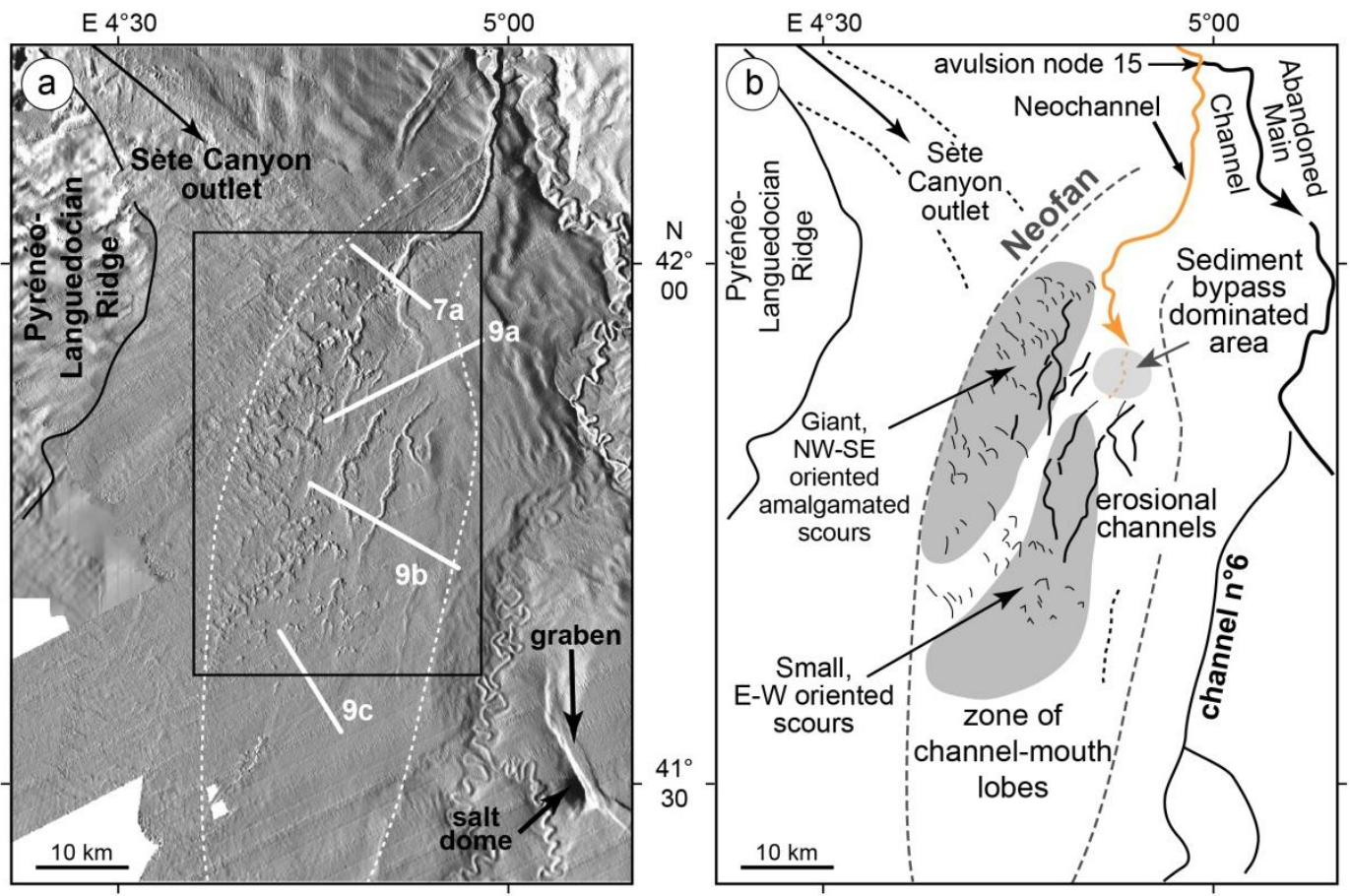

1364

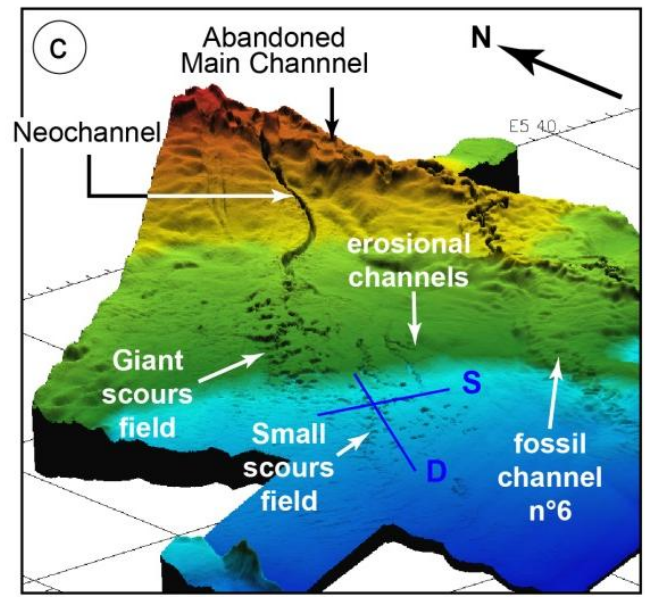

1365 Figure 8 


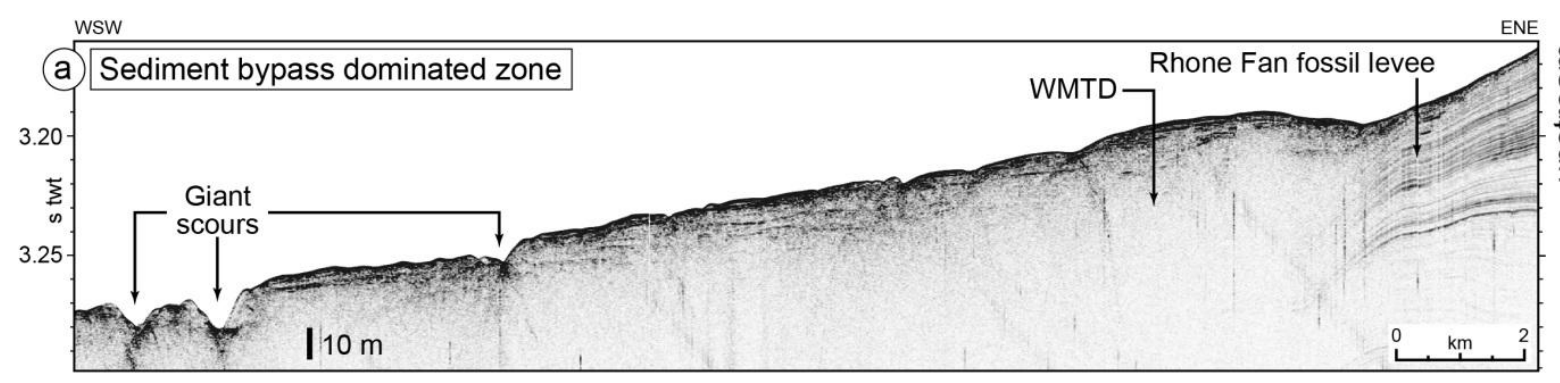

(b) Domain 2
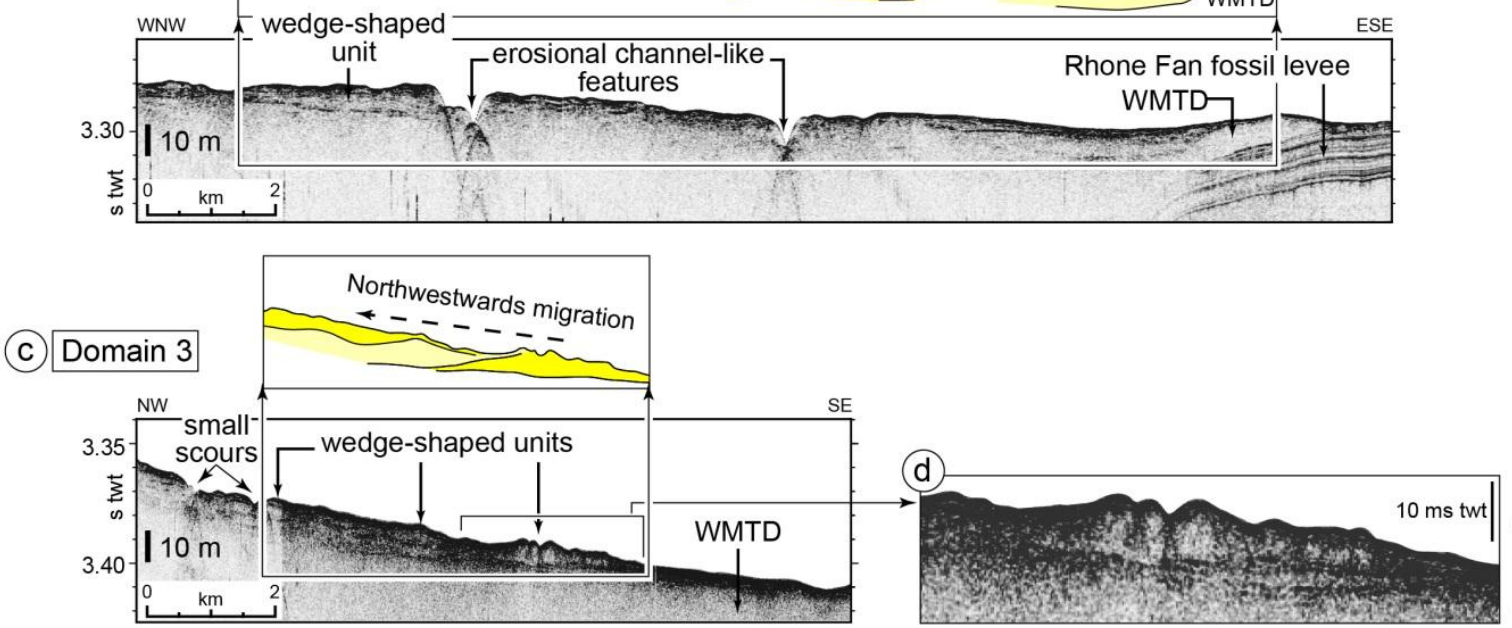

\section{Figure 9}



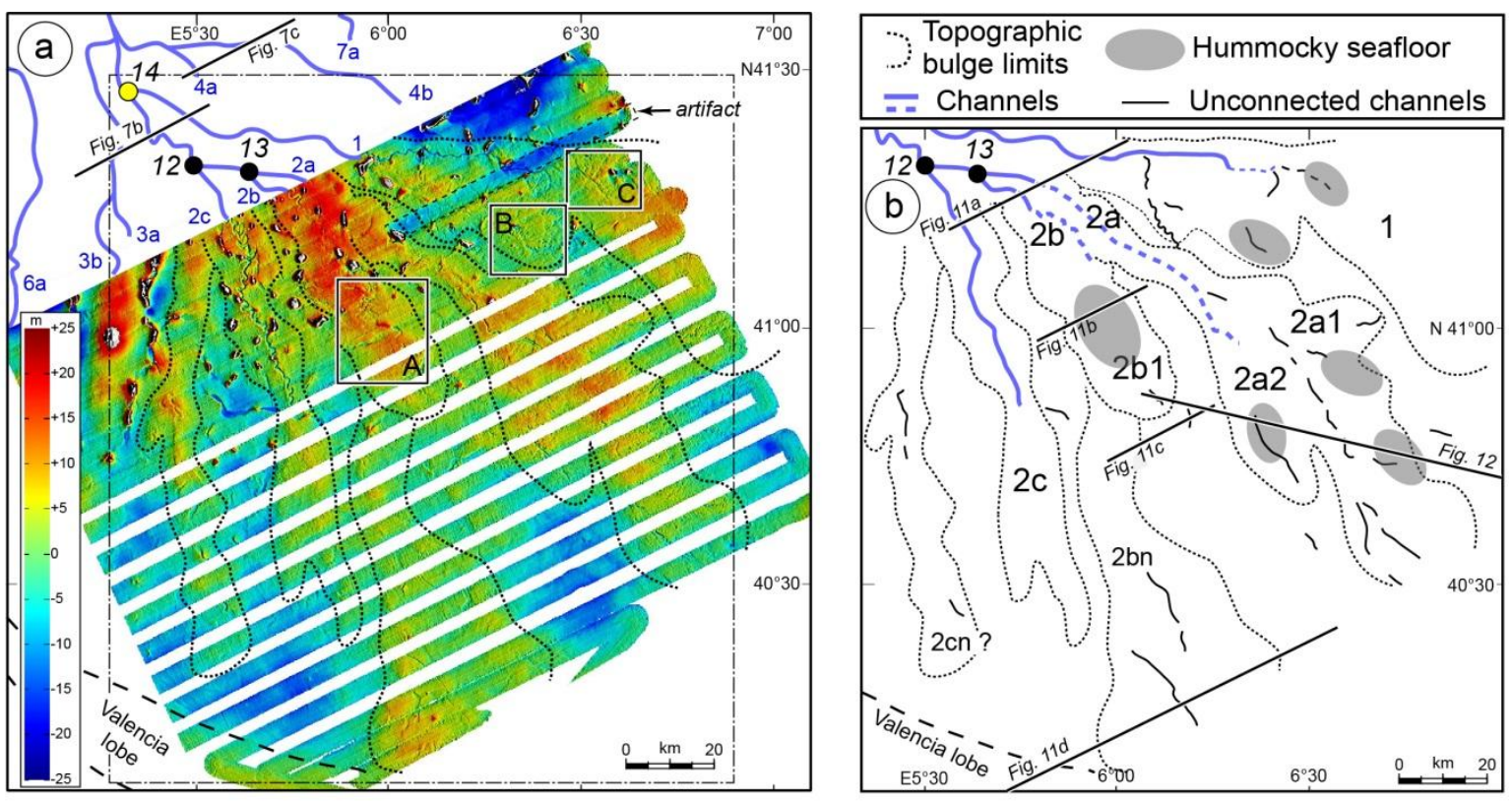

1368

Figure 10 

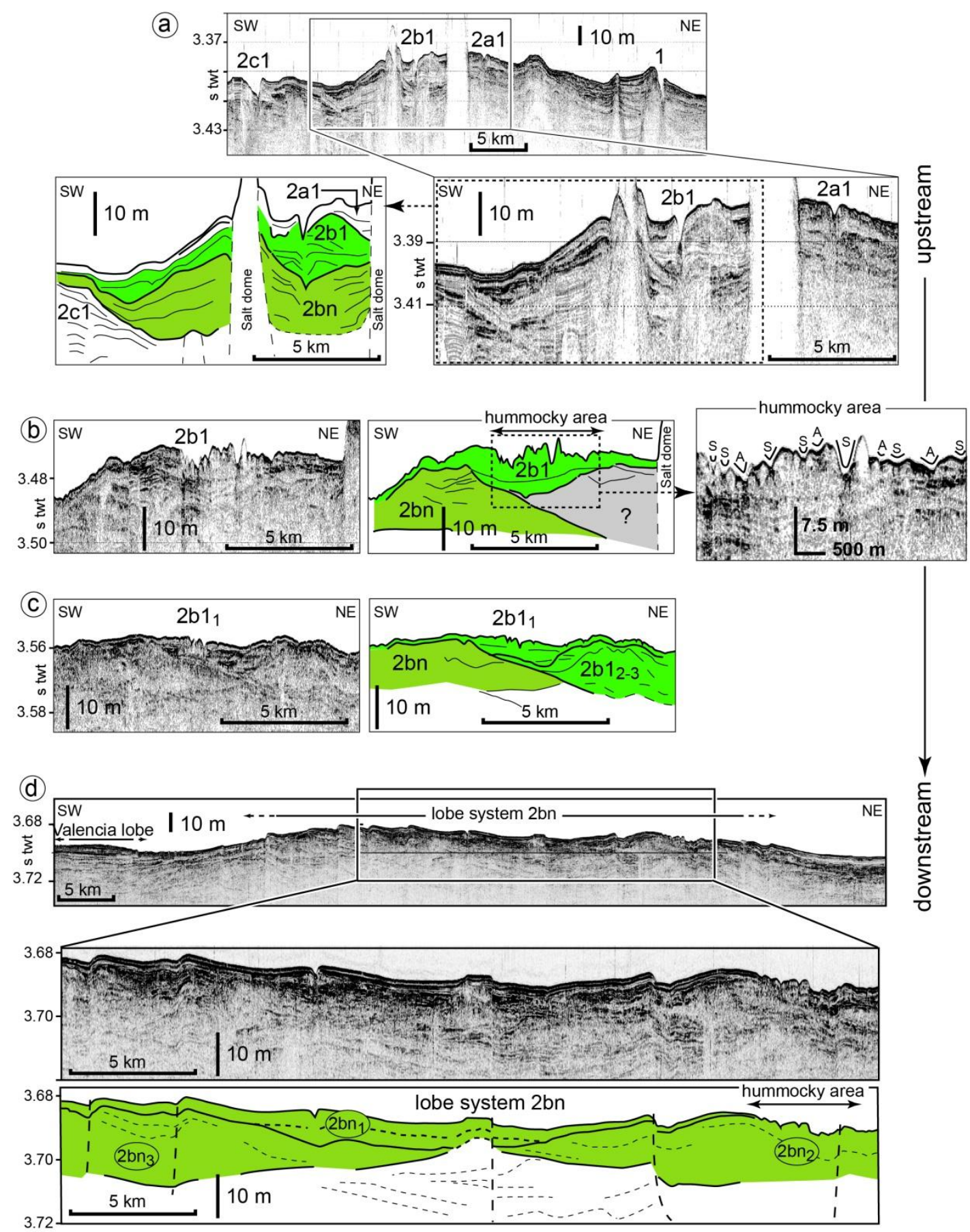

1371 Figure 11 


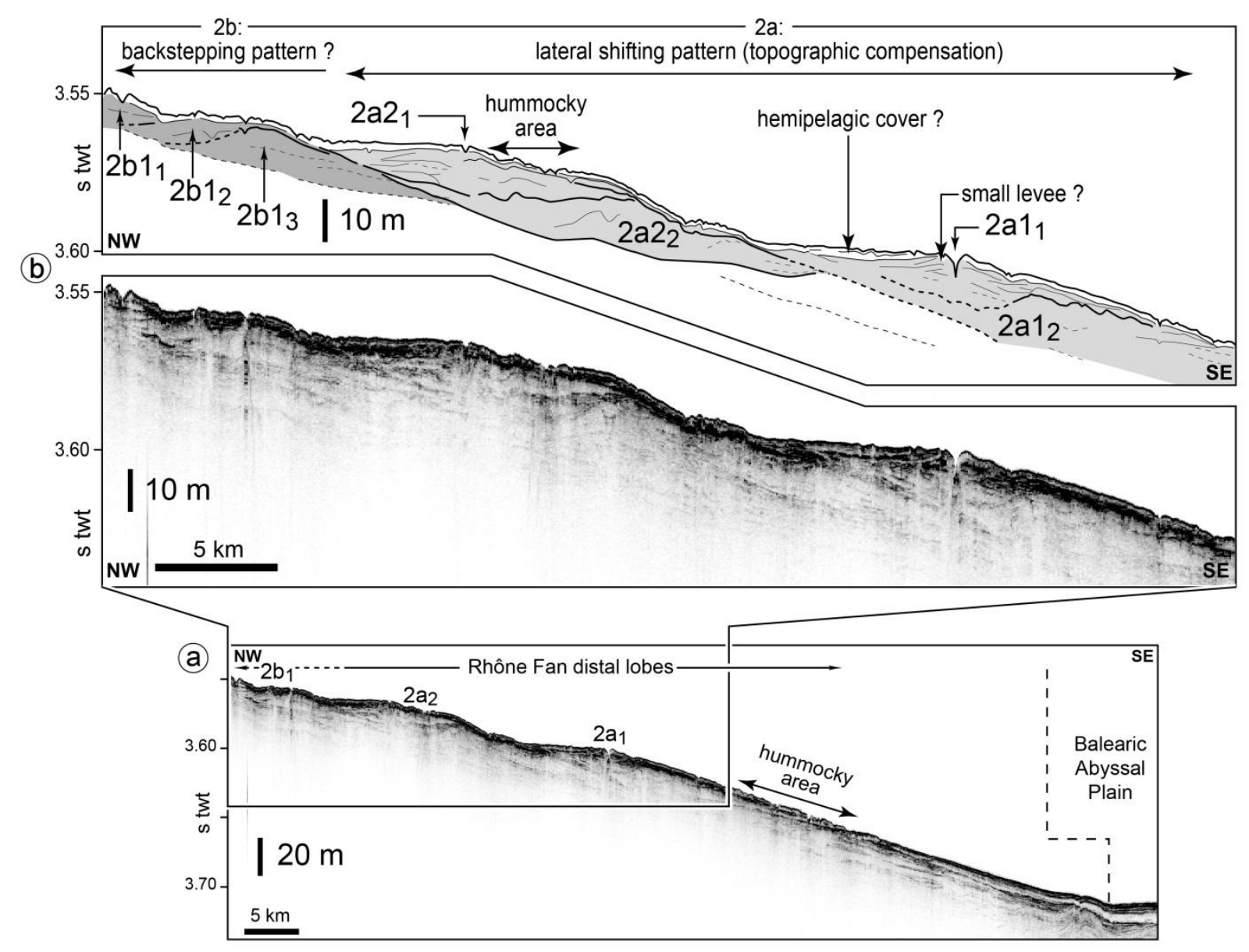

1372

1373 Figure 12 

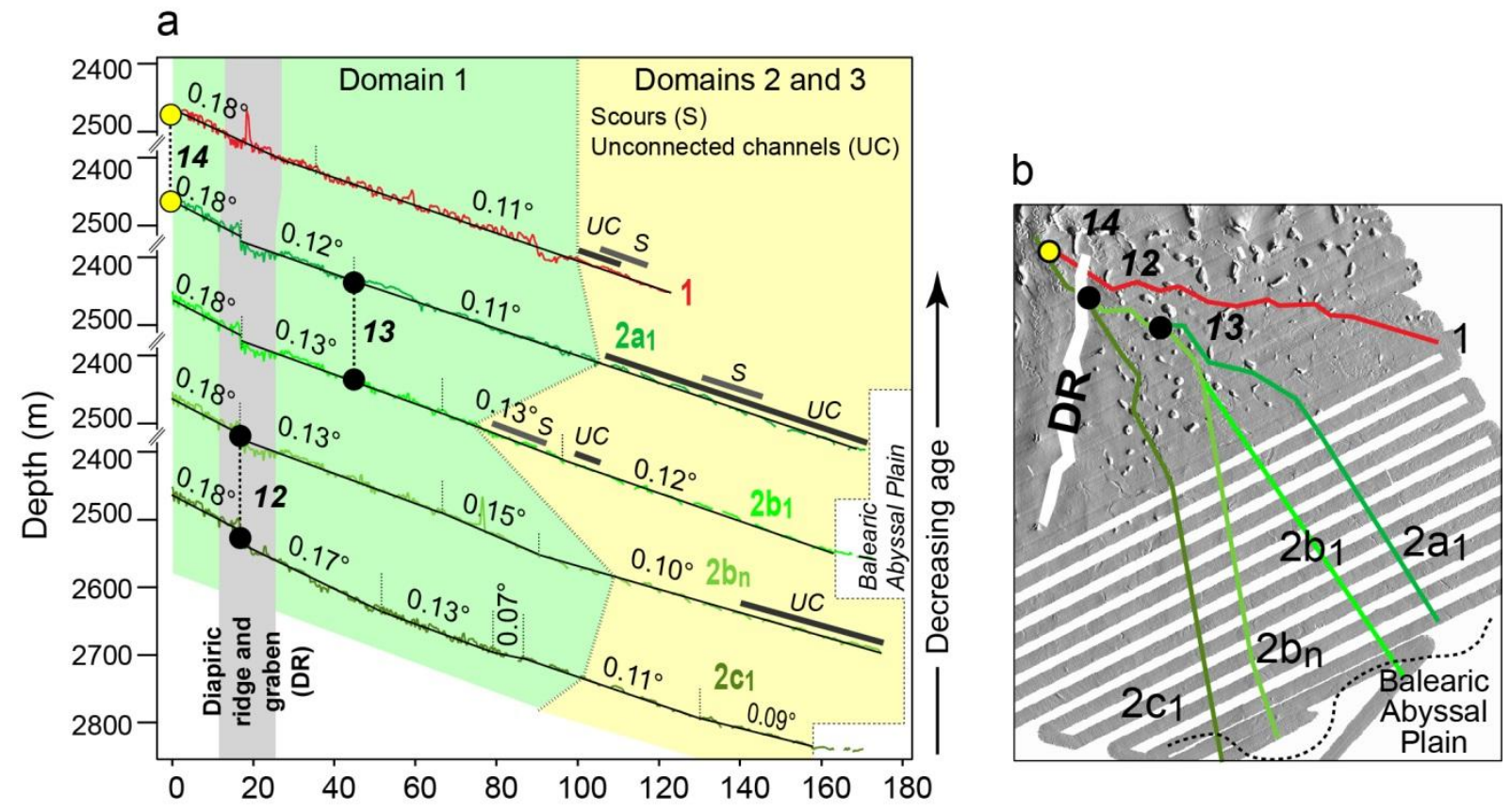

\section{Figure 13}



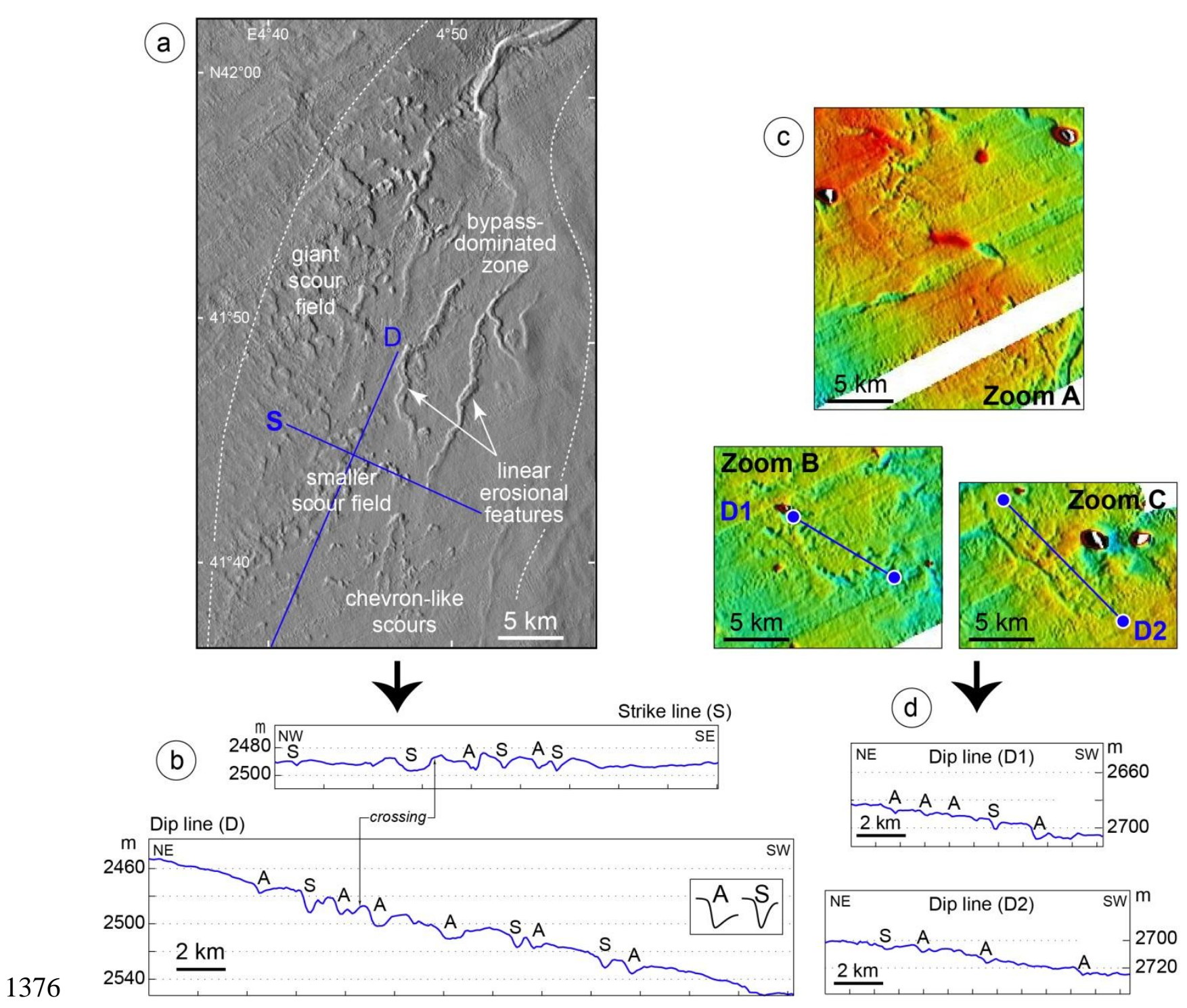

1377 Figure 14 


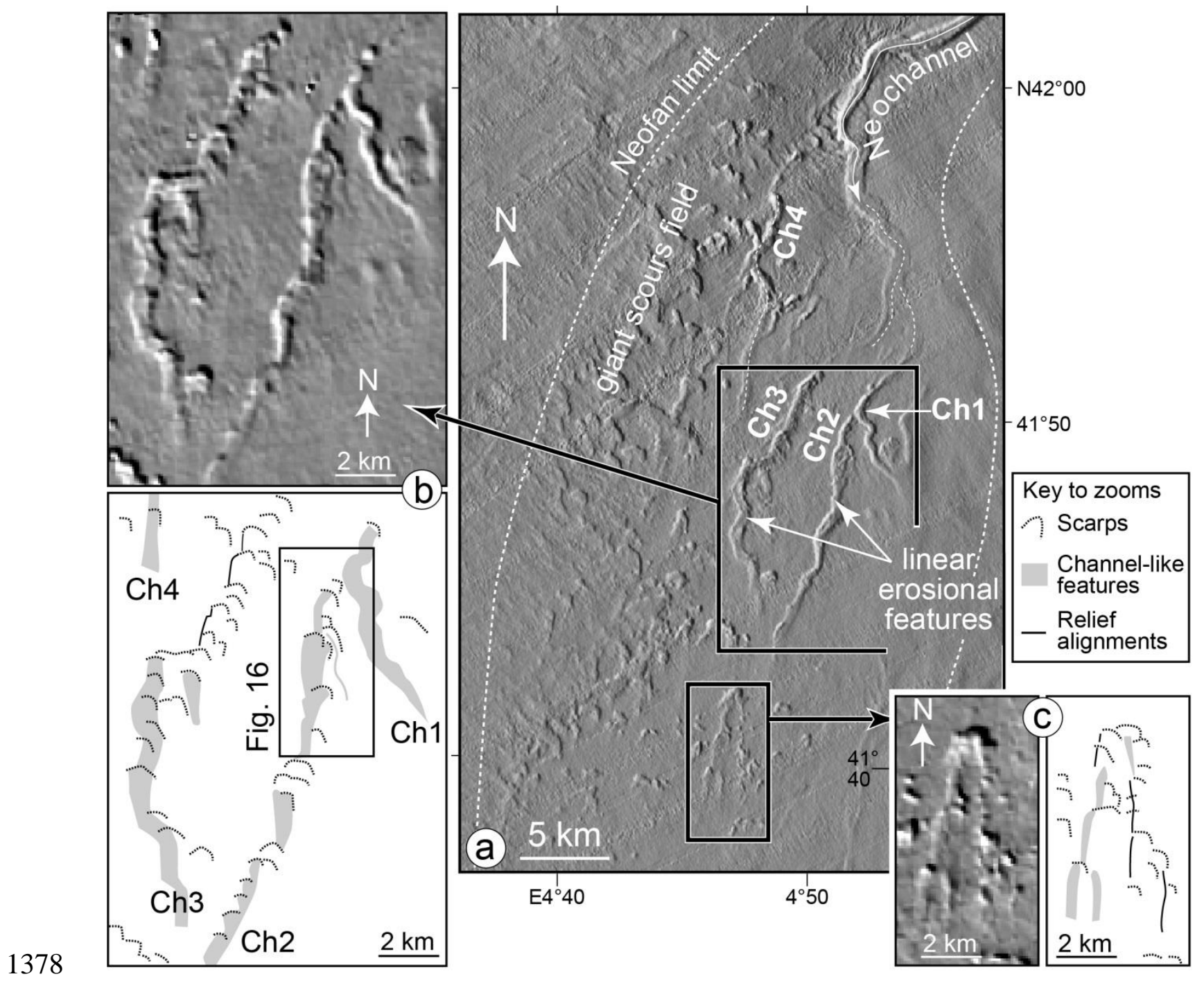

1379 Figure 15 


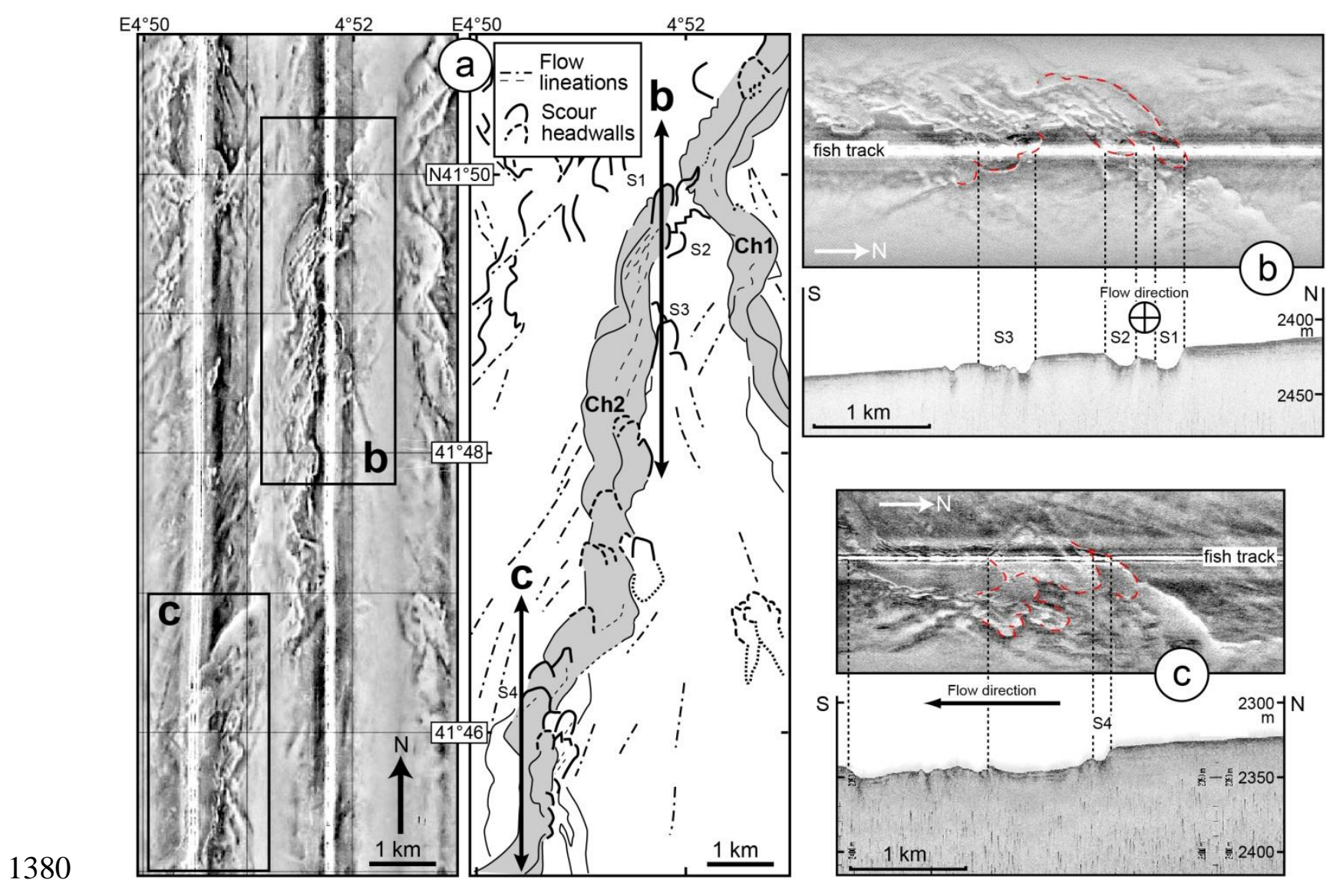

$1381 \quad$ Figure 16 




1383 Figure 17 

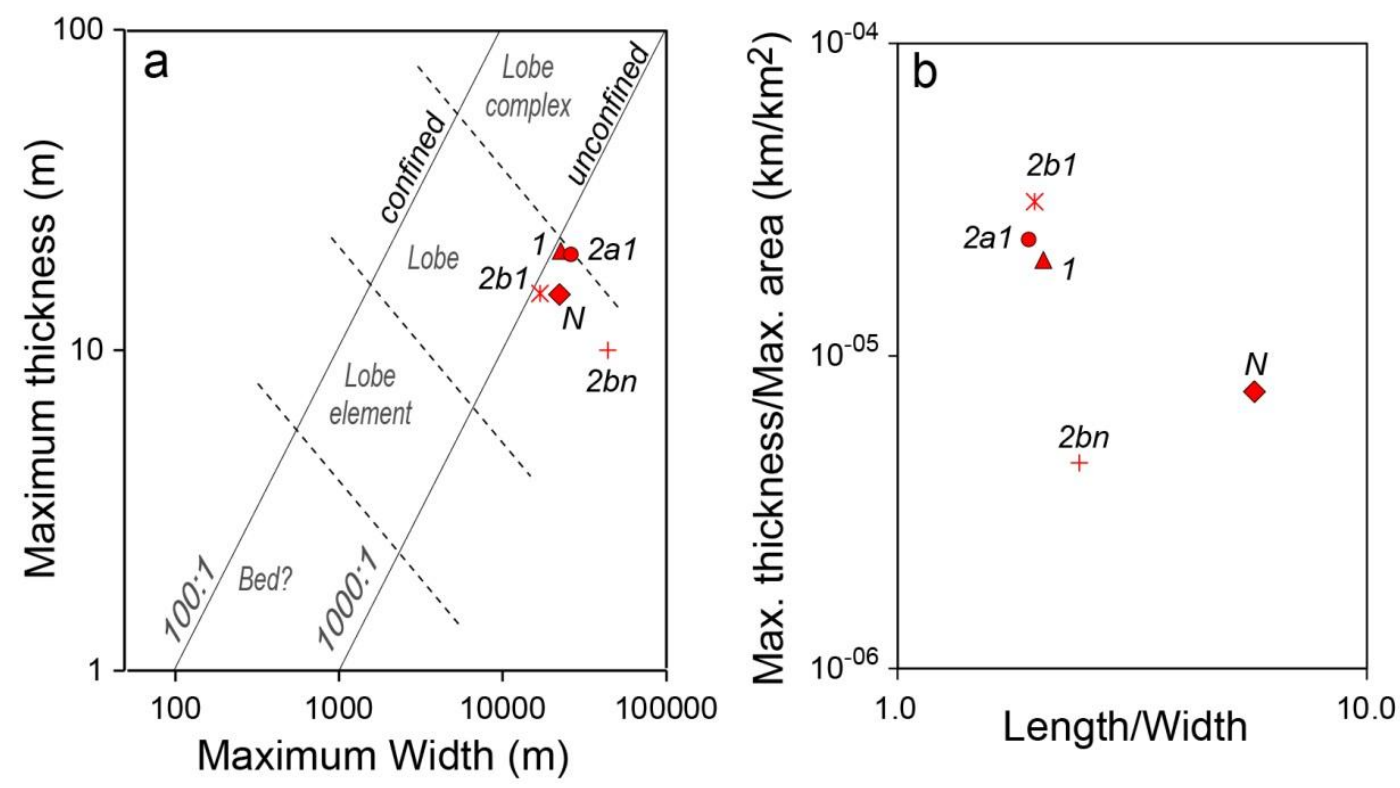

1384

1385 Figure 18 



Figure 19 


\begin{tabular}{|c|c|c|}
\hline \multicolumn{3}{|c|}{ Late Quaternary Rhône fan (Late Upper Complex) } \\
\hline Total width (TW, km) & & \\
\hline \multirow[t]{2}{*}{$\begin{array}{l}\text { Total length from the } \\
\text { canyon head (TL, km) }\end{array}$} & & \\
\hline & Neofan & $2 \mathrm{c}$ to 1 \\
\hline Water depth $(m)$ & $2000-2600$ & $2100-2855$ \\
\hline Mean slope $\left({ }^{\circ}\right)$ & 0.20 & 0.12 \\
\hline Age (cal. ka) & $21-18.5$ & $>21$ \\
\hline $\begin{array}{l}\text { Distance from canyon } \\
\text { head to avulsion nodes } \\
(\mathrm{km})\end{array}$ & D15: 119 & D15+D14: 208 \\
\hline
\end{tabular}

1388

1389 Table 1 


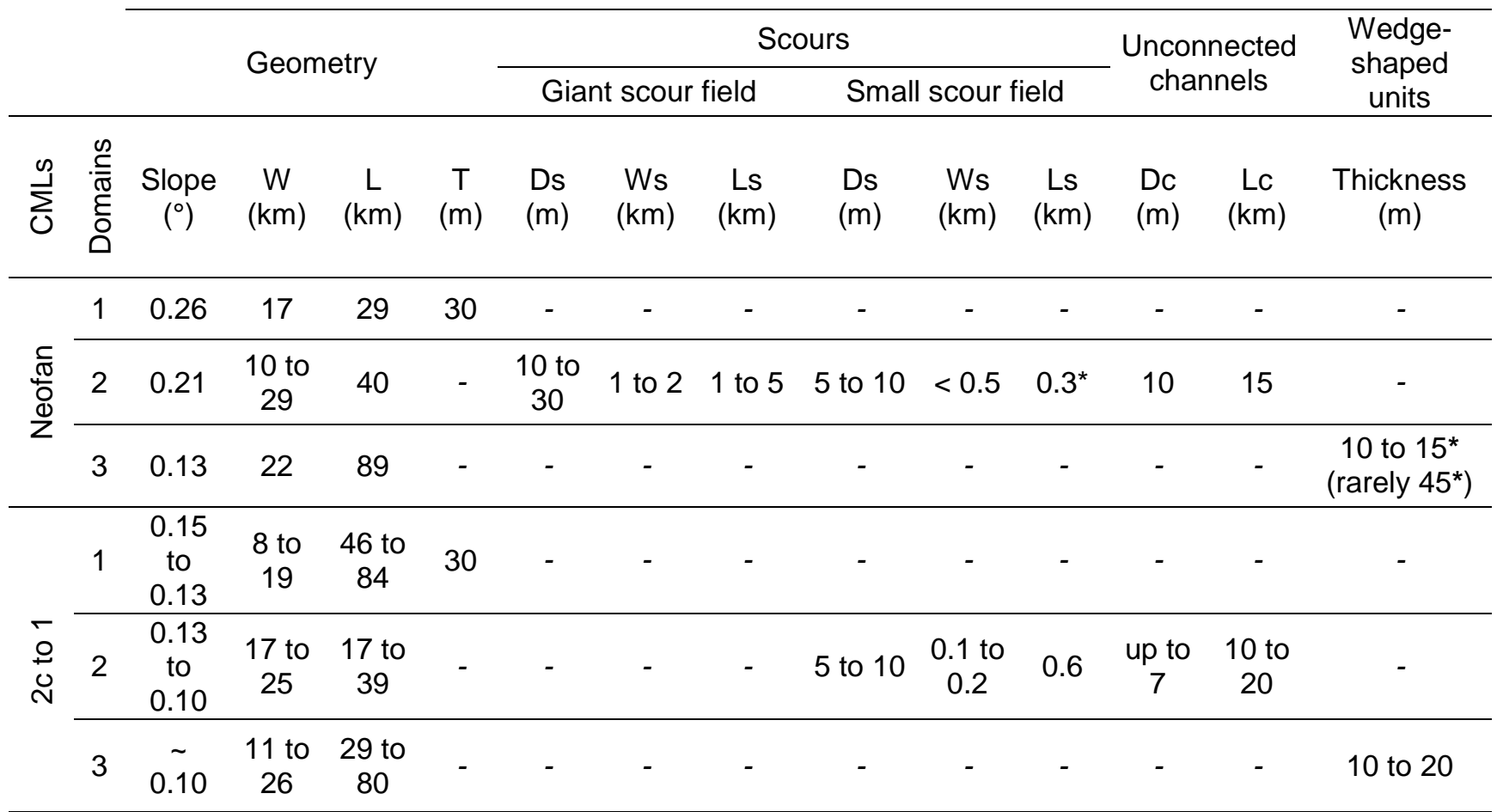

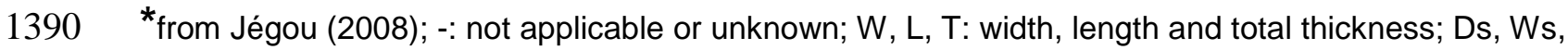
1391 Ls: scours depth, width and length, respectively; Dc, Lc: unconnected channels depth and length, 1392 respectively.

1393

1394 Table 2 
